المشكلات الزراعية بقرى مراقبة الانطلاق للتنمية و التعاون بمحافظة البحيرة إسماعيل عبد المالك محمد إسماعيل

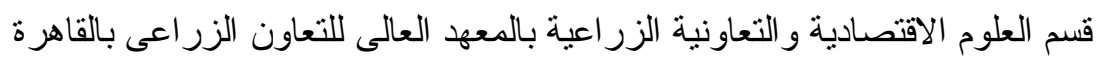
Received on: 3/2/2020 Accepted for publication on: 18/2/2020

الملخص

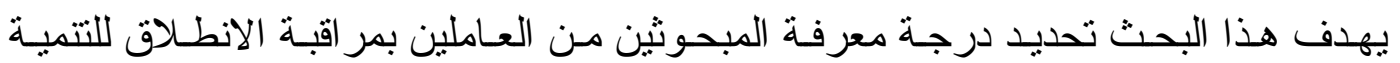

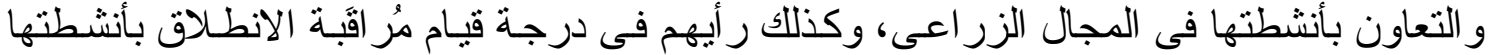

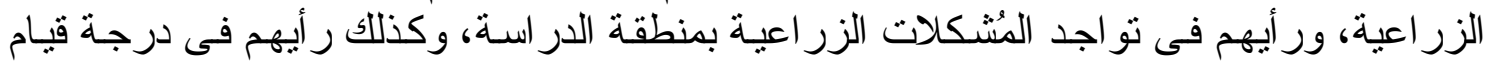

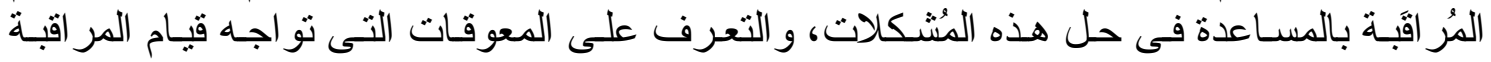

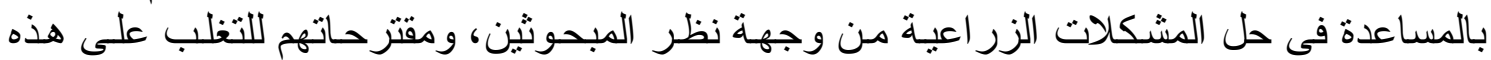

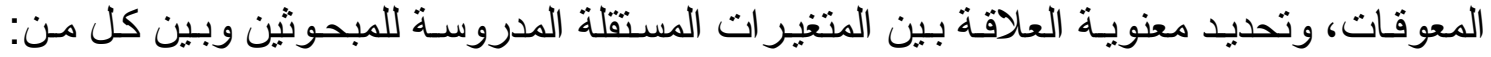

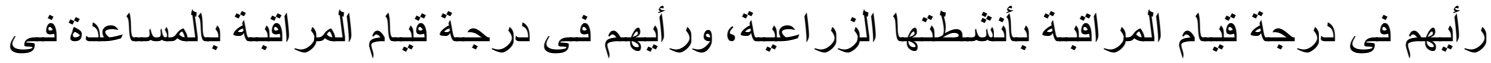

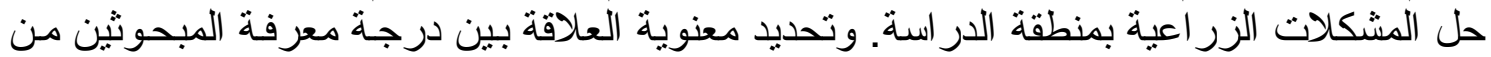

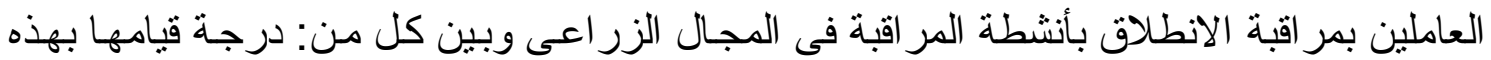

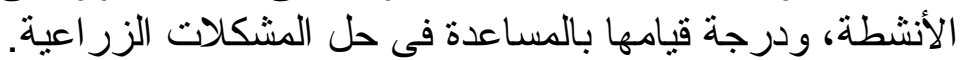

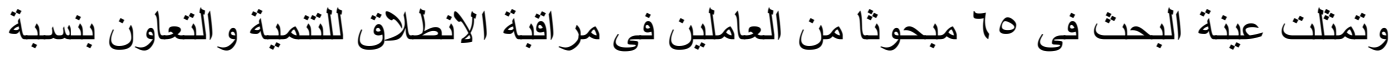

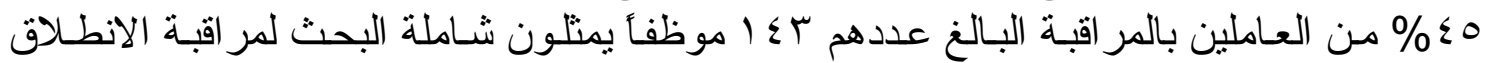

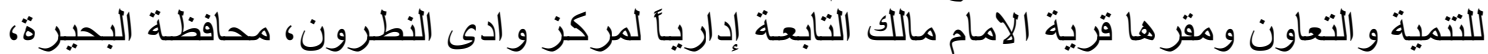

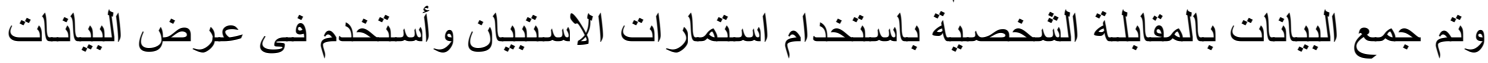

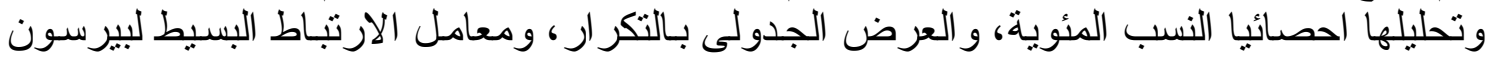

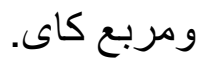

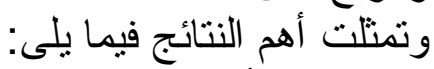

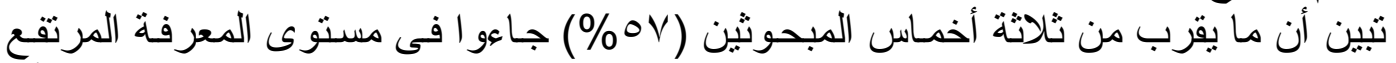

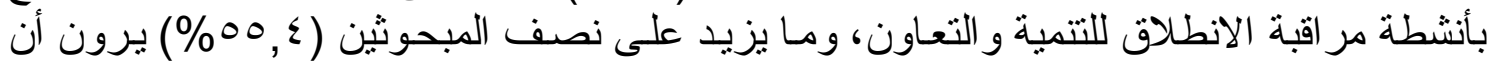

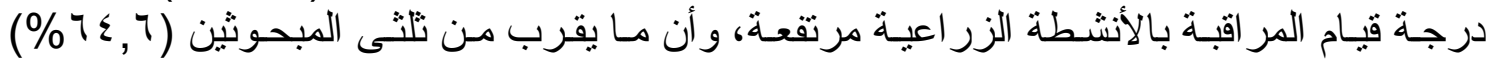

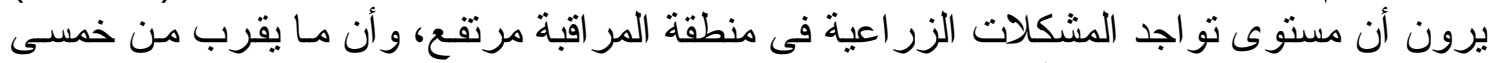

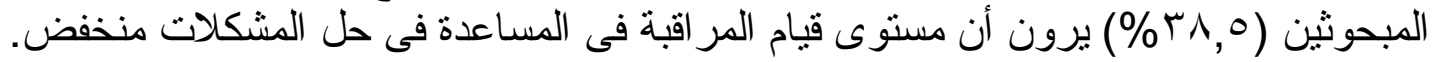

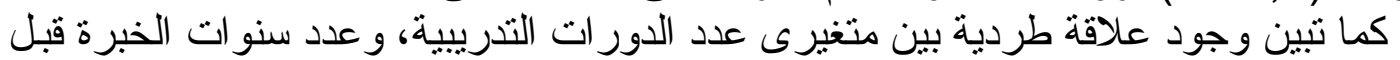

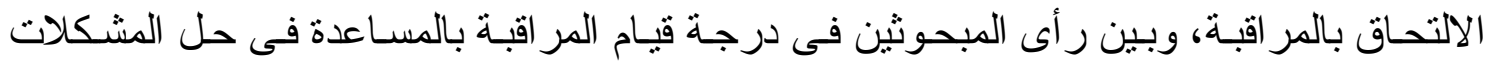

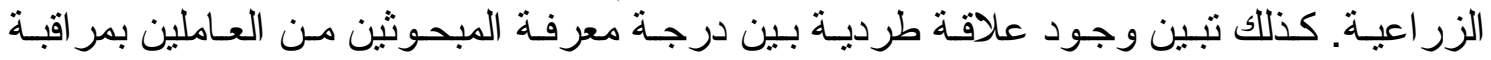

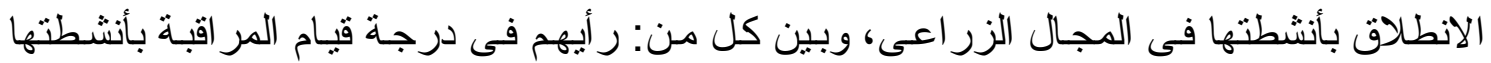

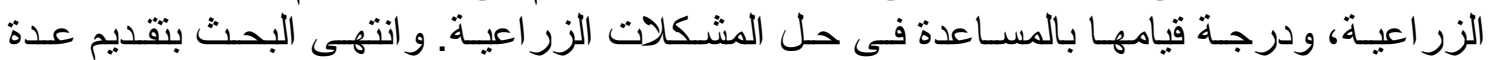
توصيات يمكن أخذها فى الاعتبار.

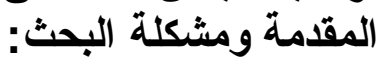

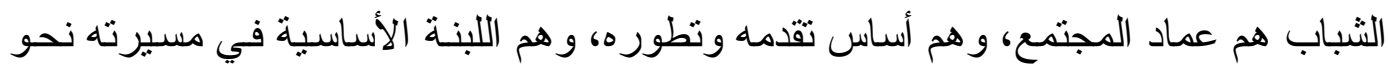

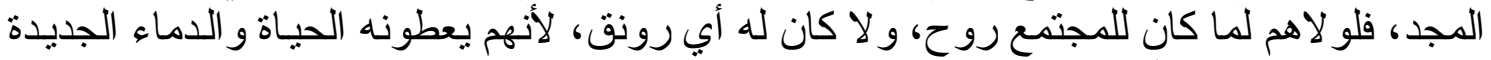

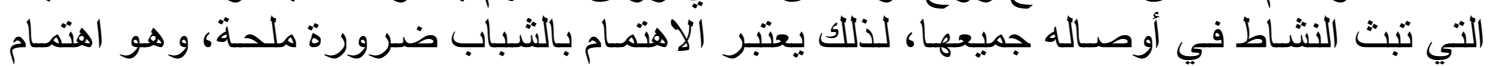
ويحظى الثباب في جميع المجتمعات بالعناية و الرعاية أكثر من أبي فئَة أخرى من فئَات

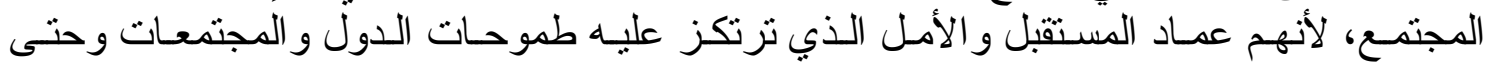

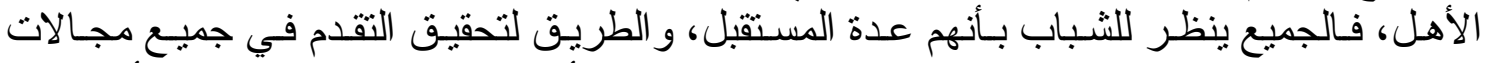

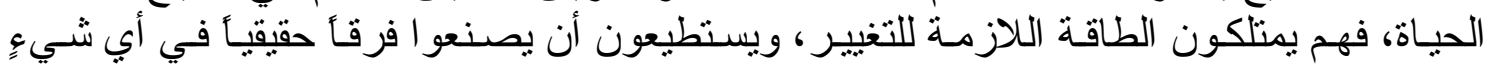




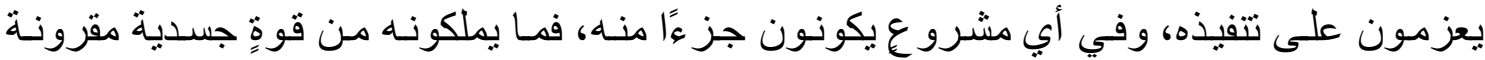

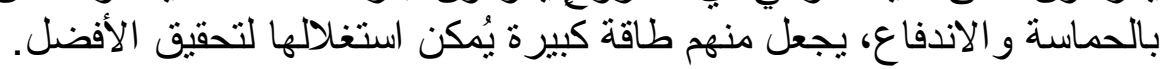

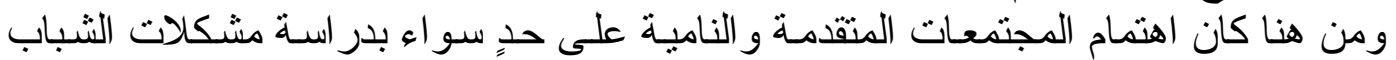

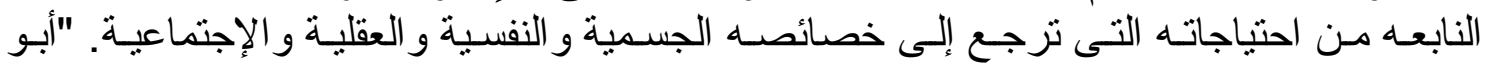

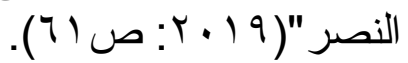

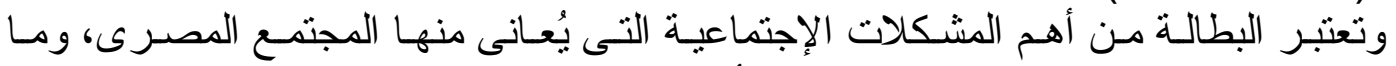

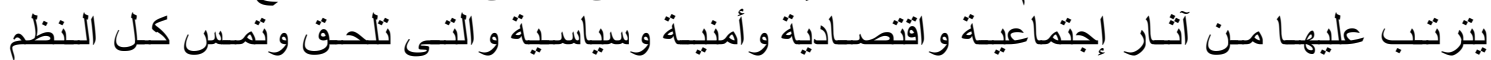

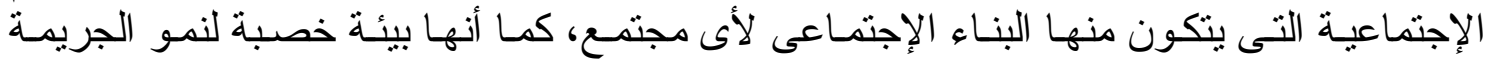

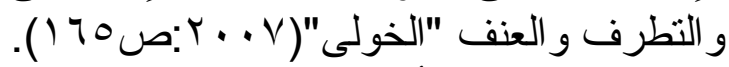

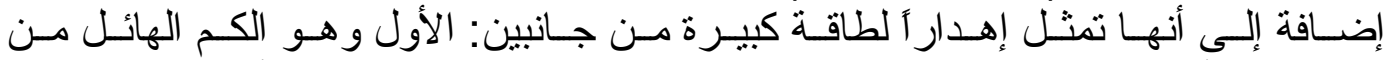

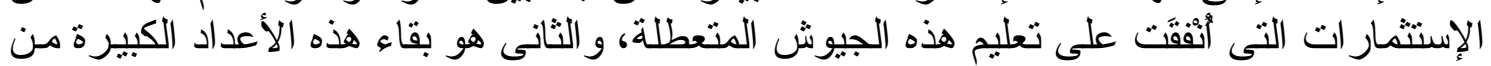

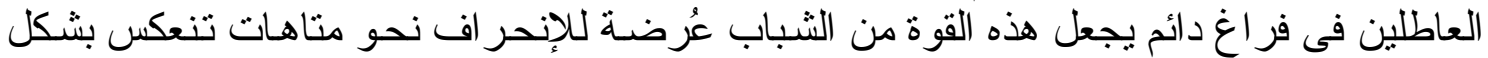

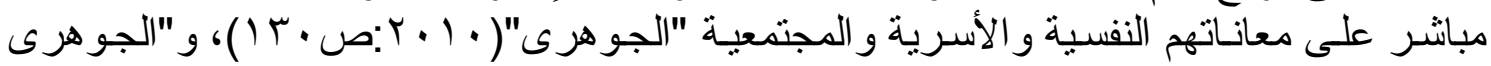

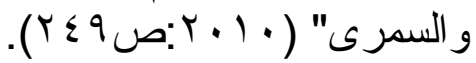

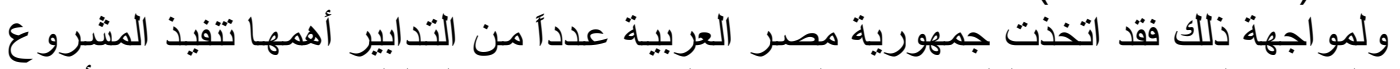

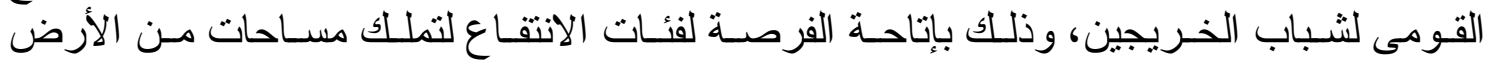

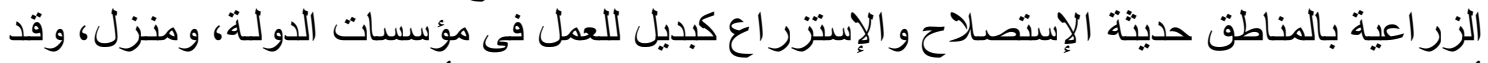

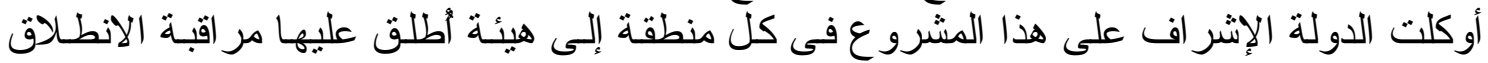

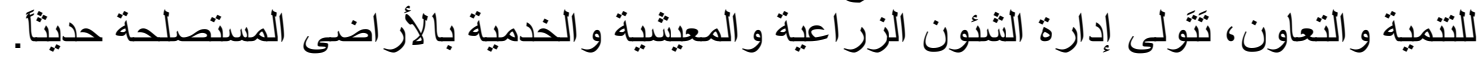

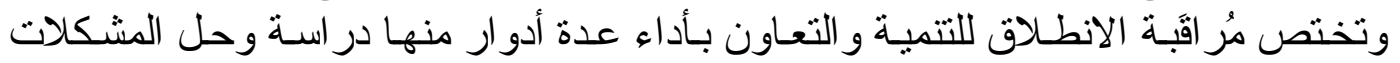

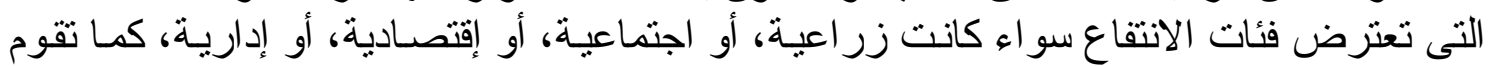

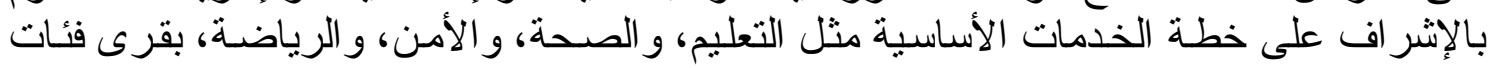

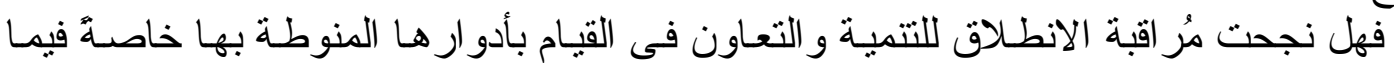
الانتفاع.

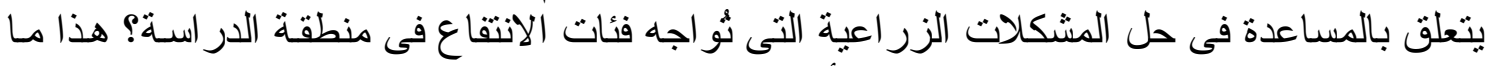

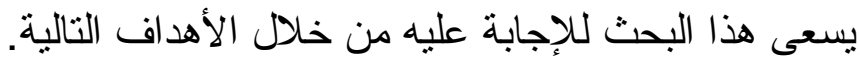
أهداف البحث: البحث:

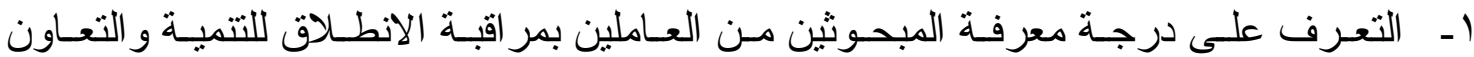
بأنشطتها الزر اعية.

r- التعرف على درجة قيام مُر اقَبة الانطلاق للتتمية و التعاون بأنشطتها الزر اعية.

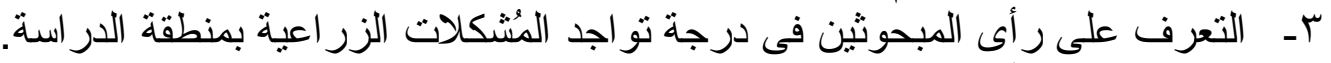

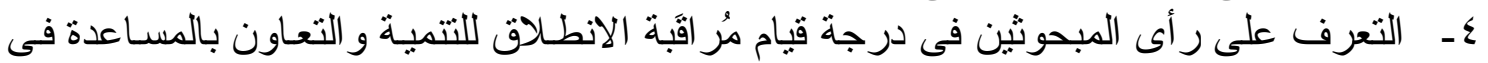

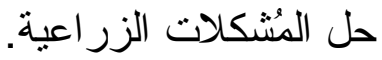

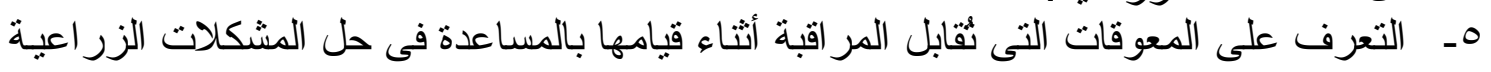
من وجهة نظر المبحوثين.

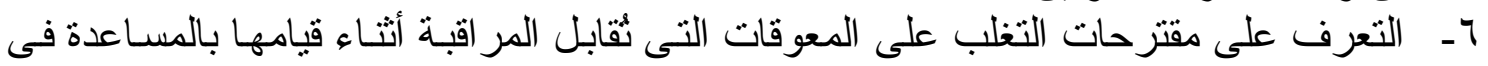
حل المشكلات الزر اعية من وجهة نظر المبحوثين.

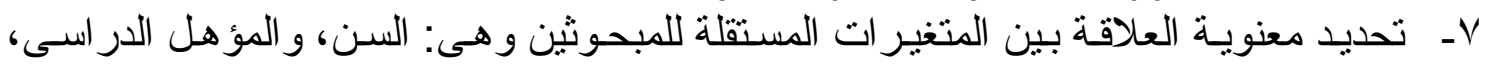

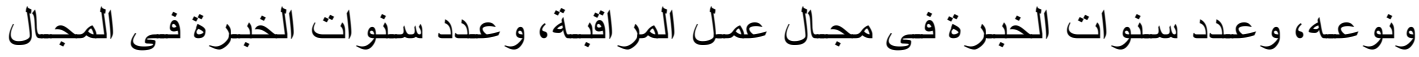

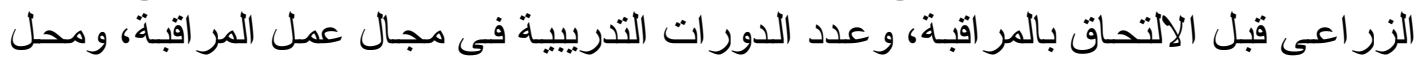

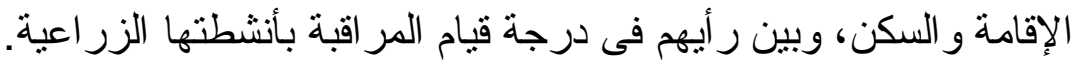


^ـ - تحديد معنوية العلاقة بين المتغير ات المستقلة المدروسة، وبين رأى المبحوثين فى درجة قيام

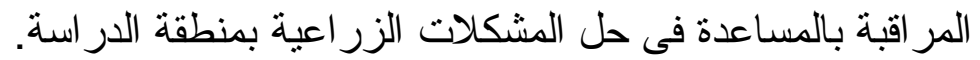

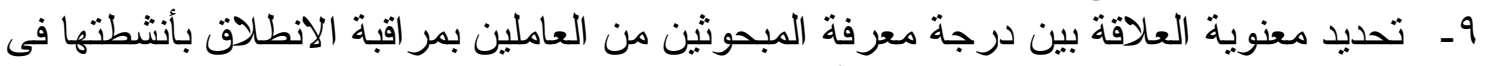

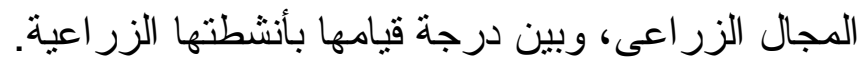

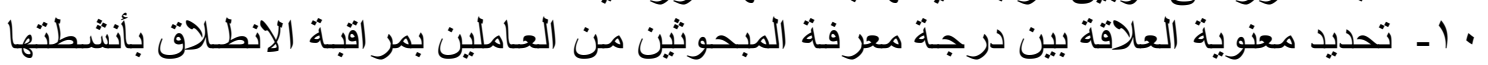

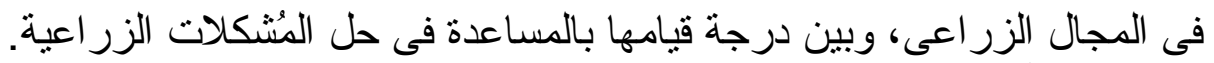
الفروض البحثية: لتحقيق الأهداف من السابع إلى العاشر تم صباغة الفروض الأتية:

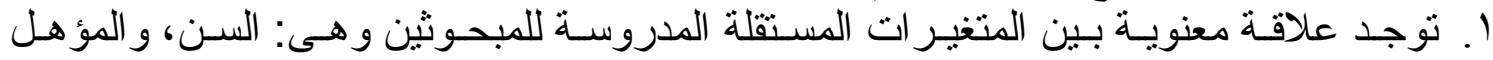

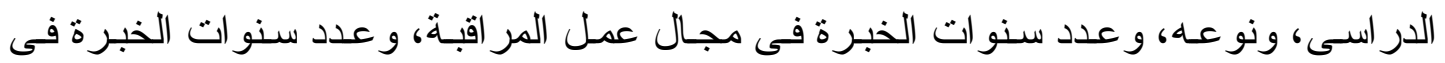

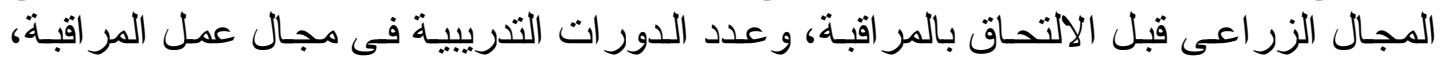

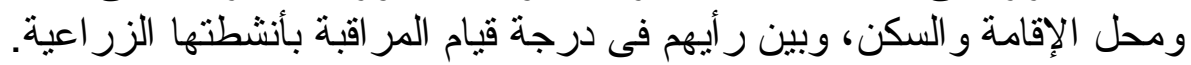

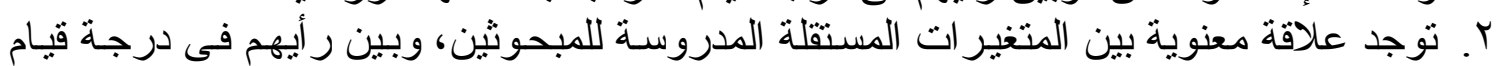

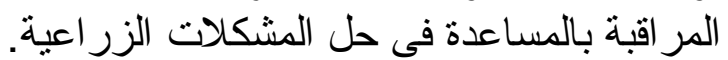

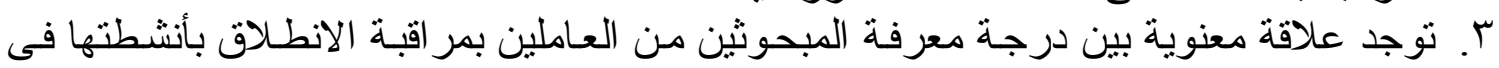

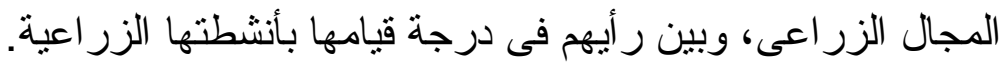

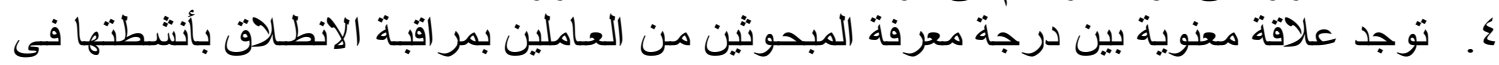

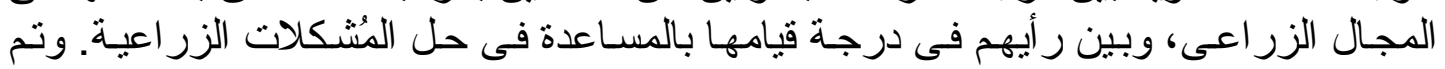

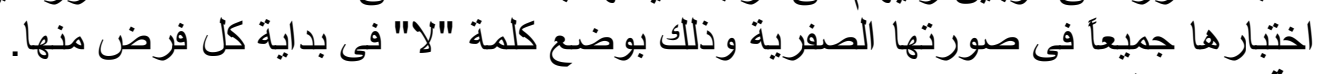

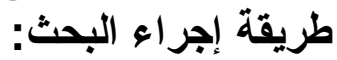

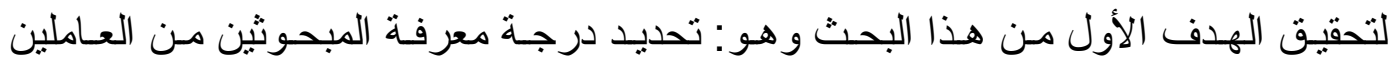

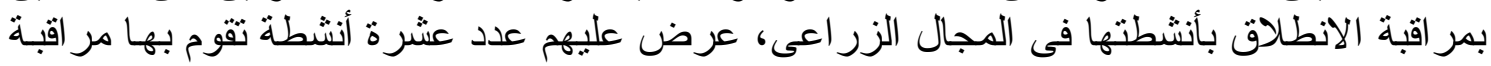

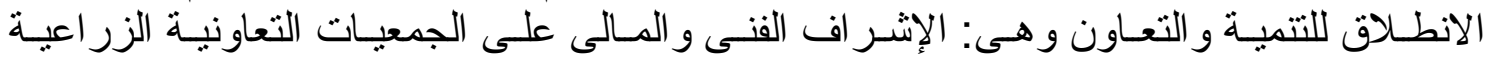

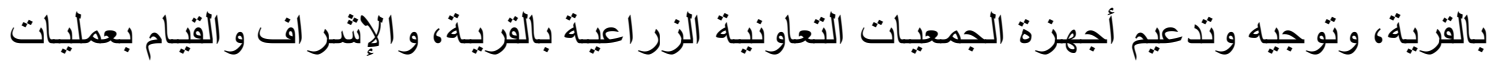

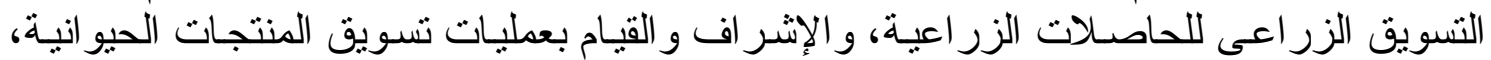

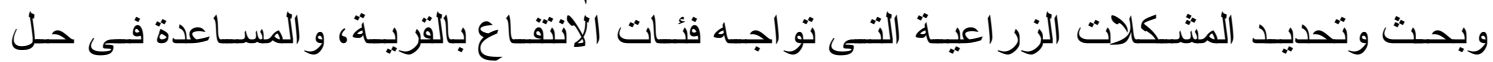

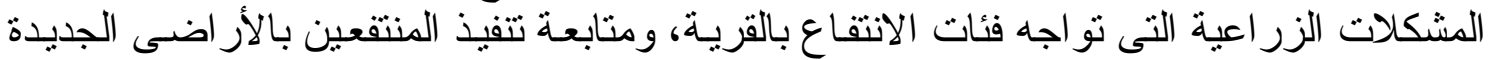

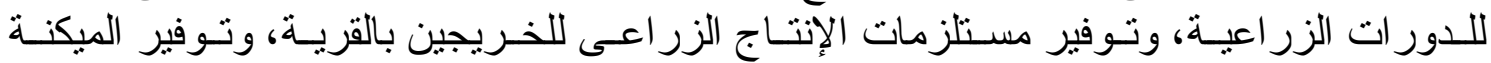

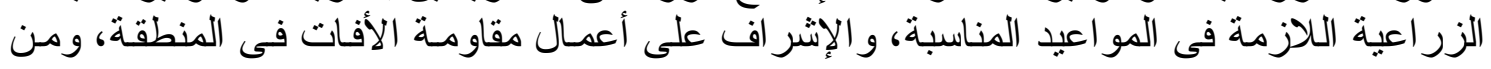

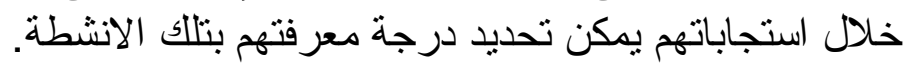

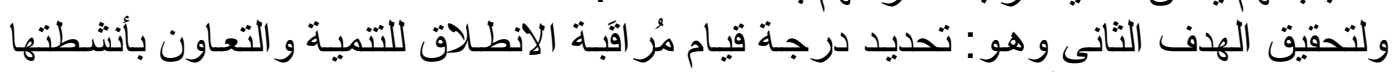

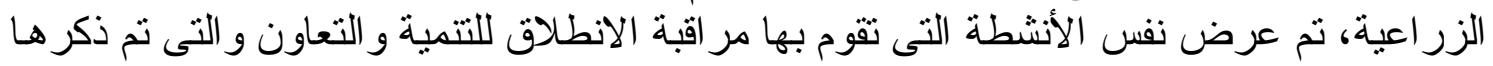

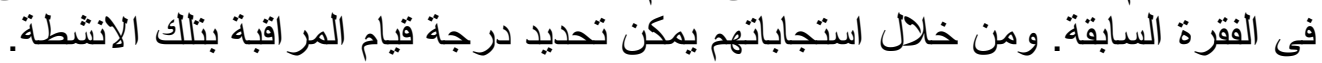

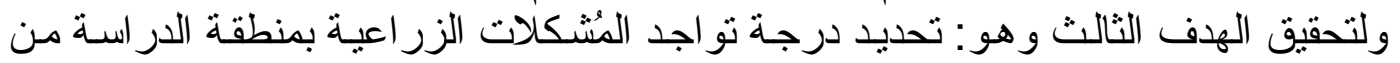

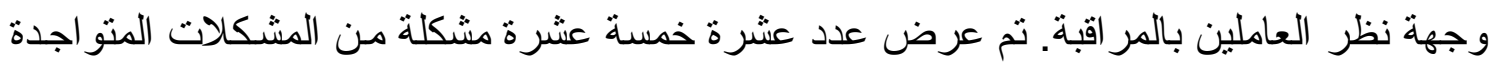

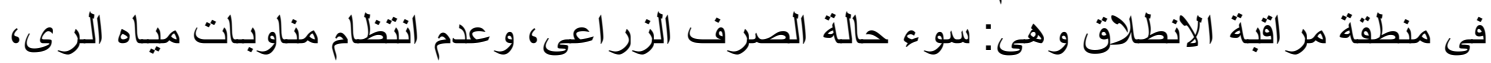

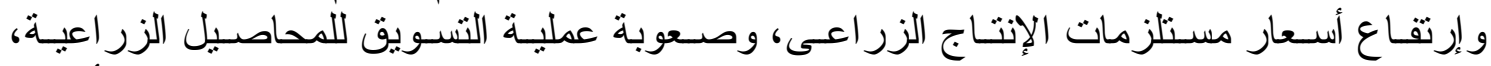

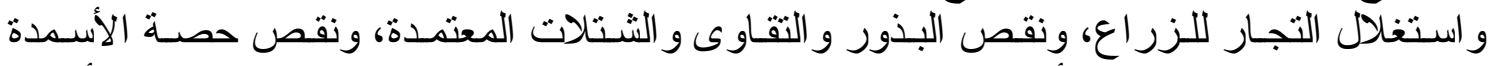

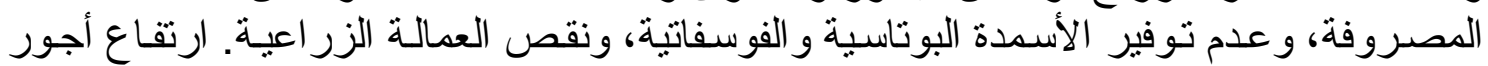

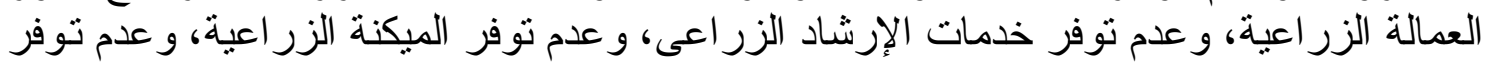

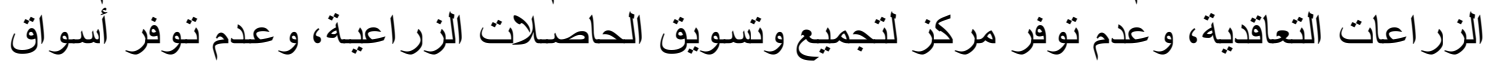




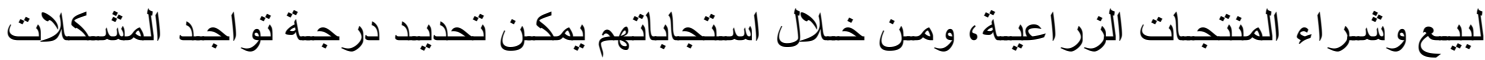

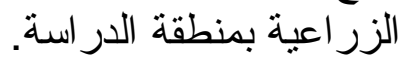

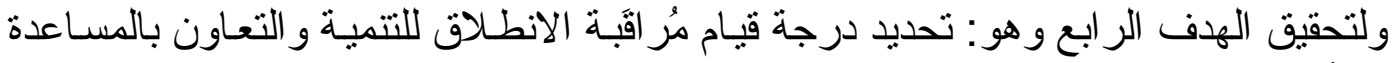

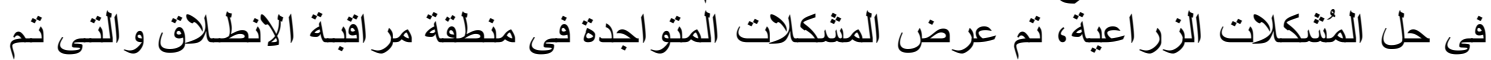

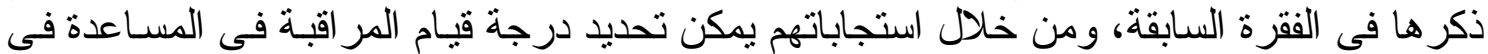
حل تلاك المشكلات.

وقد تم وضع ماسبق بالإضافة إلى بعض المتغير ات المستقلة فى استمارة استبيان تم إعدادها

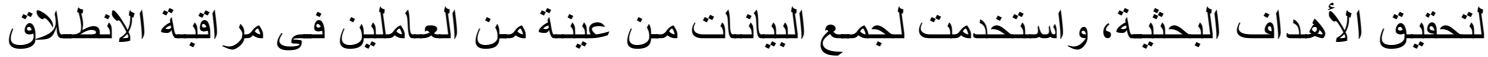

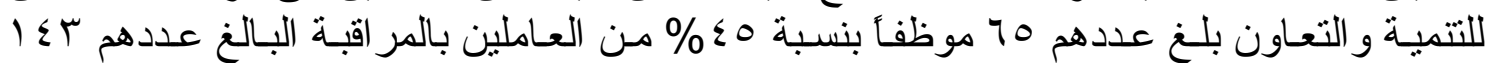

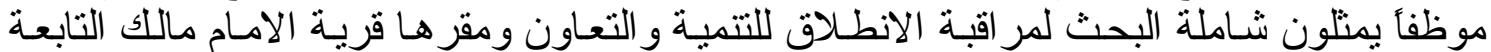

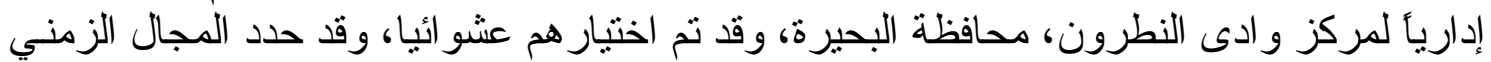

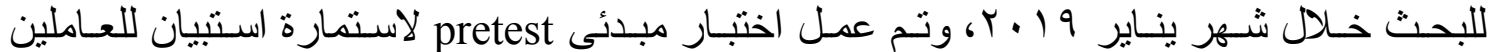

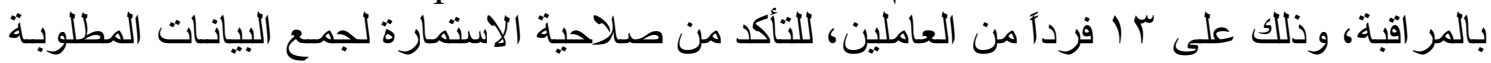

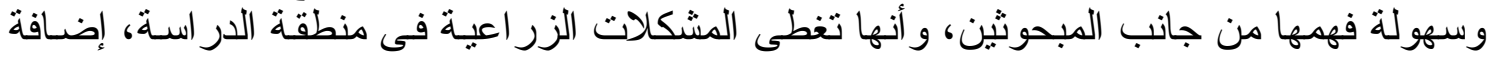

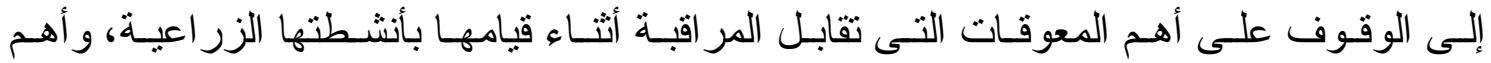

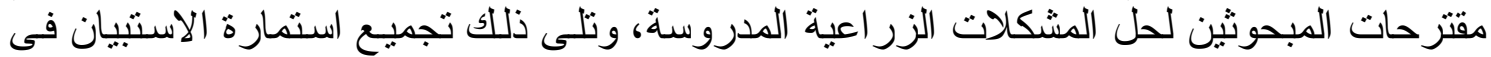

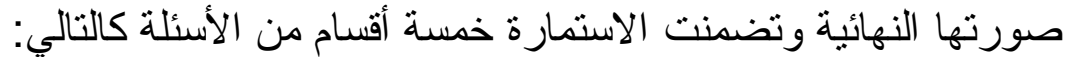

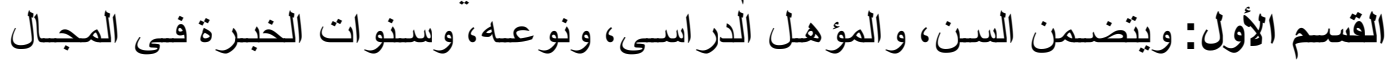

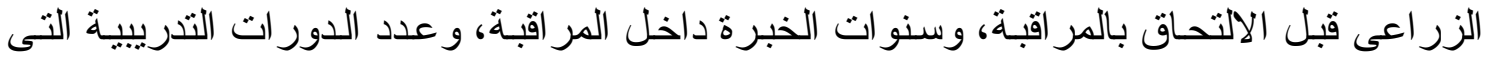

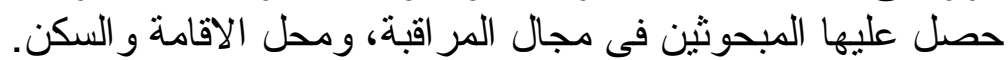

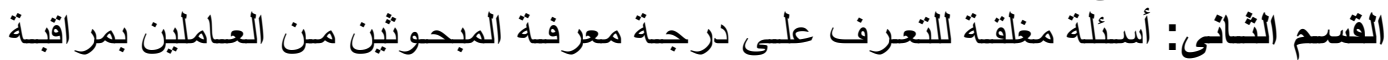

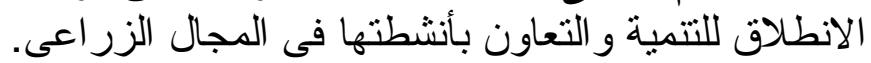

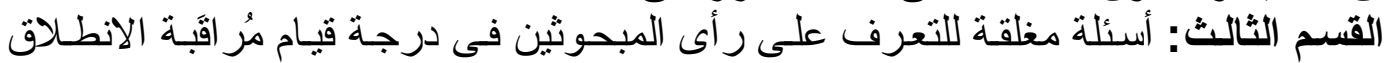
للتتمية و التعاون بأنشطتها الزر اعية.

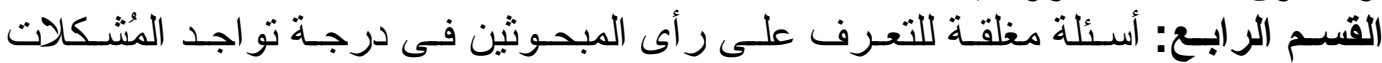
الزر اعية بمنطقة الدر اسة من وجهة نظر العاملين بالمر اقبة.

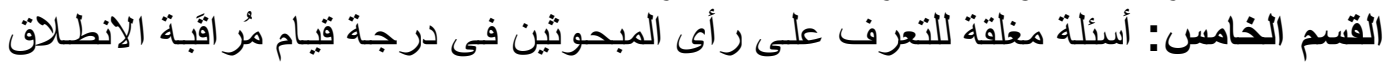

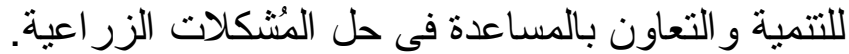

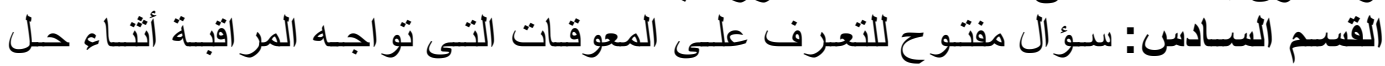
المشكلات الزر اعية من وجهة نظر المبحوثين.

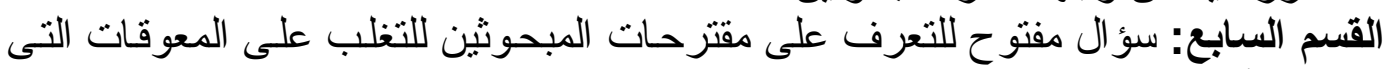

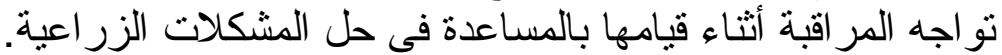
المعالجة الكمية للبيانات : بعد الإنتهاء من جمع البيانات البات تم تفريغها ومعالجتها كميا.

أولاً: وصف عينة البحث: تبين من النتائج الواردة بجدول رقم ( (1) أن خصـائص عينـة البحث من

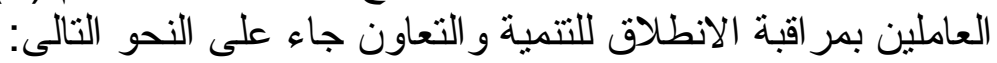

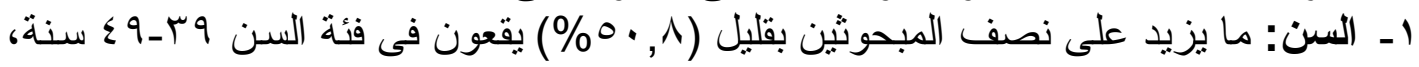

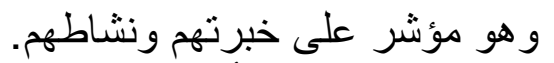

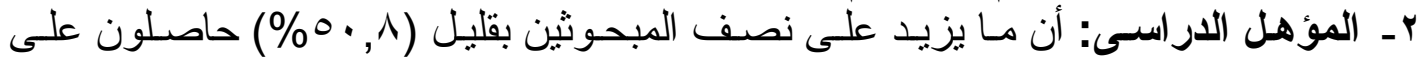

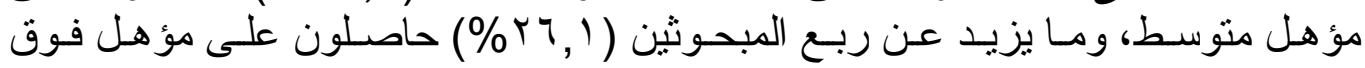

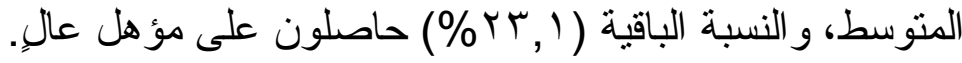




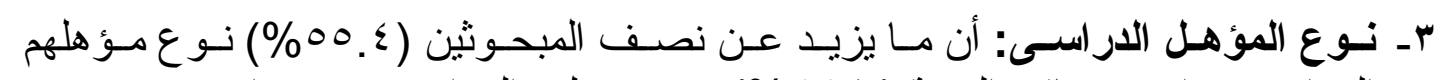

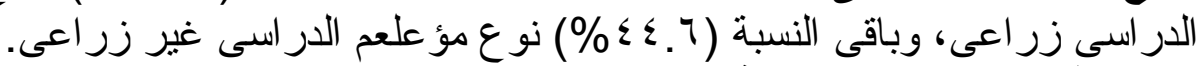

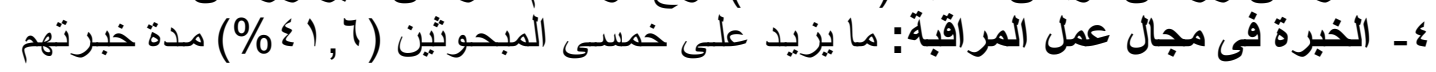

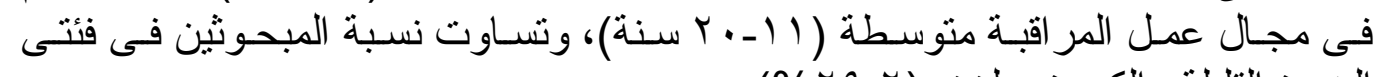

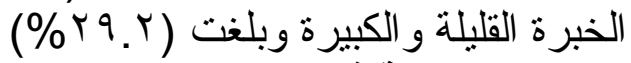

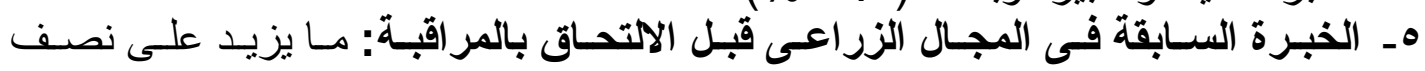

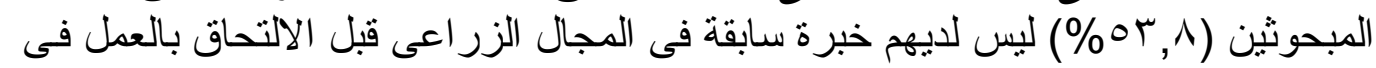

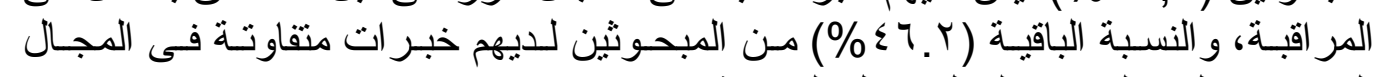

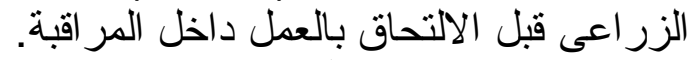

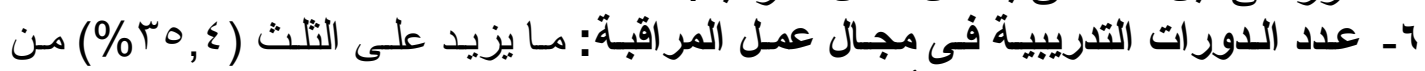

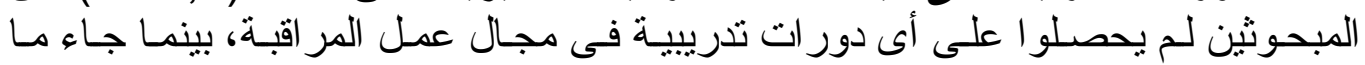

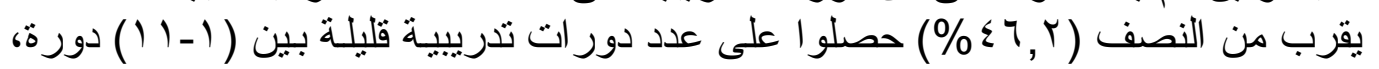

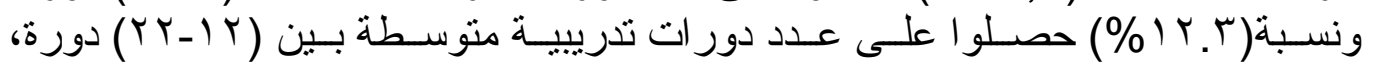

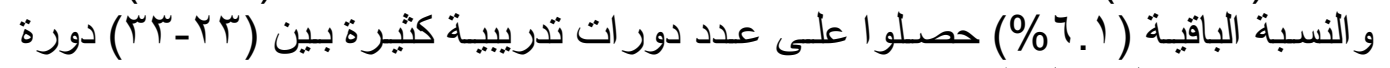

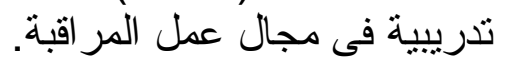

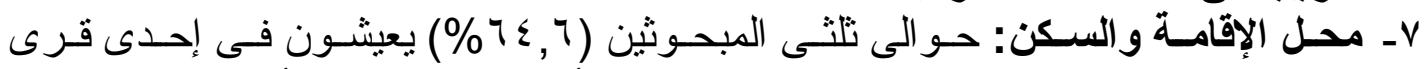

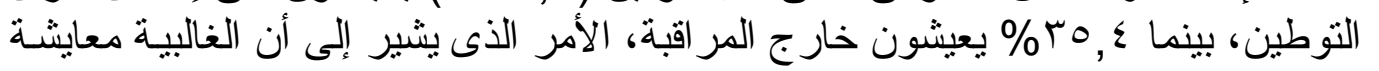
للمشكلات الزر اعية الموجود بقرى المئون 
جدول 1 ـ توزيع المبحوثين من العاملين بالمر اقبة وفقاً لمتغير اتهم الثخصية المدروسة.

\begin{tabular}{|c|c|c|c|c|c|}
\hline$\%$ & عدد & المتفير ات الشخصية & $\%$ & عدد & المتغير ات الثخصية \\
\hline & & •. الخبرة السابقة فى المجال الزراعى قبل & & & 1 السن: \\
\hline & & الالتحاق بالمر اقبة: & $r\rceil, 1$ & iv & 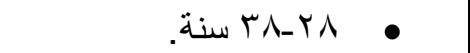 \\
\hline or, , & ro & • لا توجد خبرة سابقة. & $0 \cdot, \wedge$ & r & 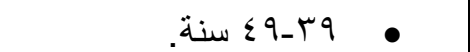 \\
\hline$r v$ & $r \varepsilon$ & 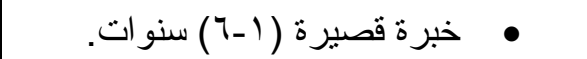 & $r+$, & 10 & ( ) .09_0. سنة. \\
\hline$\varepsilon, 7$ & r & • خبرة منوسطة (Y-V ( ) سنة. & & & \\
\hline$\varepsilon, 7$ & $r$ & 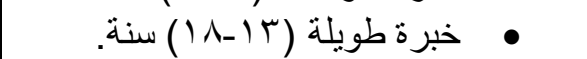 & & & \\
\hline & & الـ اقبة: الدورات التدريبية فى مجال عمل & $0, \lambda$ & Tr & 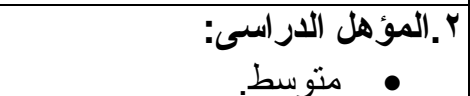 \\
\hline ro, $\varepsilon$ & r & 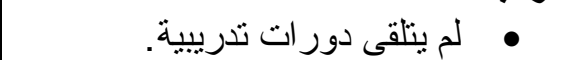 & $r \tau, 1$ & iv & فوق المنوسط. \\
\hline$\varepsilon 7, r$ & r. & •مستوى صغير (1-11) دورة. & $r$ r, & 10 & 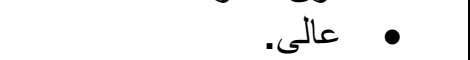 \\
\hline Ir & $\wedge$ & 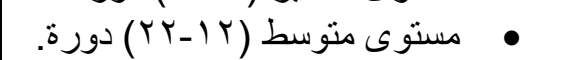 & & & \\
\hline 7,1 & $\varepsilon$ & •مستوى كبير (Tr-Tr) دورة. & & & \\
\hline \multirow{7}{*}{$\begin{array}{l}7 \leqslant, 7 \\
T 0, \xi\end{array}$} & \multirow{3}{*}{ 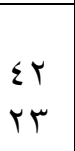 } & V. محل الإقامة و السكن: & & & آ. ـ نوع المؤهل الار اسىى: \\
\hline & & • فى إحدى قرى المر اقبة & $00, \varepsilon$ & ד & 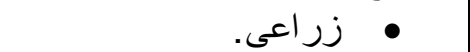 \\
\hline & & • ارج المر اقبة. & $\varepsilon \varepsilon, 7$ & rq & غير زر اعى \\
\hline & & & & & ع ـ الخبرة فى مجال عمل المراقبة: \\
\hline & & & $r q, r$ & 19 & • مدة قصيرة (r- - (1) سنة. \\
\hline & & & $\leqslant 1,7$ & rV & 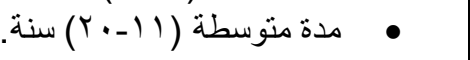 \\
\hline & & & $r q, r$ & 19 & •مدة طويلة (آ-Y-Y) سنة. \\
\hline
\end{tabular}

ثانياً: درجة معرفة المبحوثين بالأنثطة الزراعية لمر اقبة الانطلاق للتنمية و التعاون:

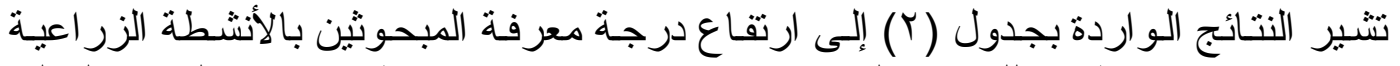

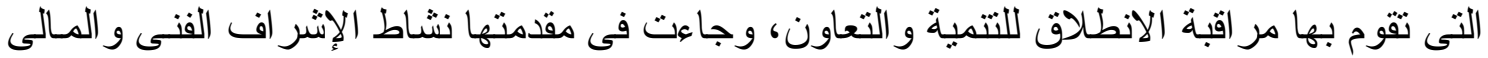

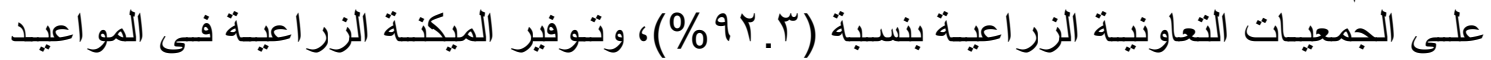

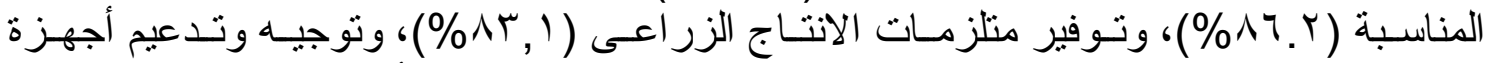

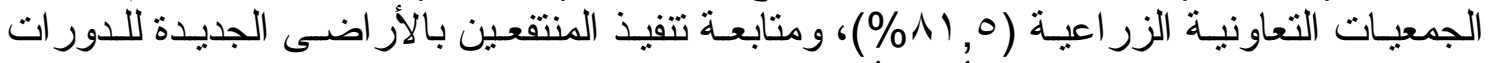

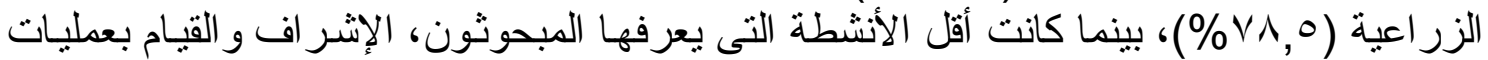

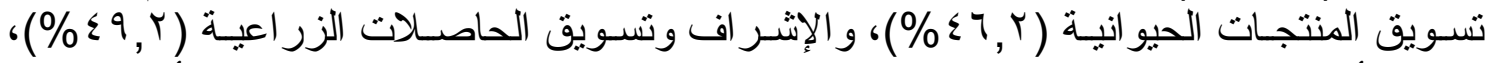

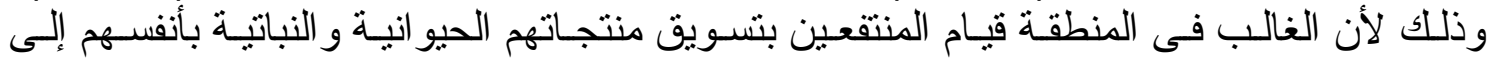
الأسواق القريبة من المنطقة كسوق السادس من أكتوبر ، وسوق الأسكندرية، و أسو اق الجملة داتلة داخل

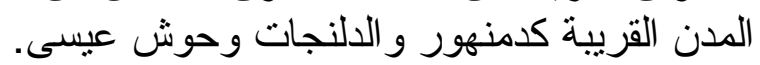

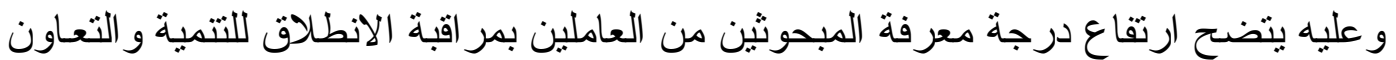

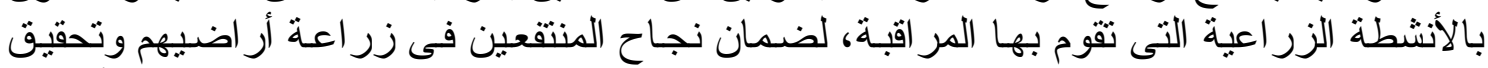

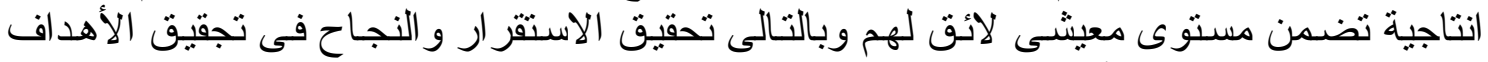
المنشودة من النوطين بالأر اضى المستصلحة حديثً. 
Assiut J. Agric. Sci., 51 (1) 2020 (217-233)

ISSN: 1110-0486

Website:www.aun.edu.eg/faculty_agriculture/journals_issues_form.php E-mail: ajas@aun.edu.eg

جدول r. توزيع المبحوثين من العاملين بالمر اقبة وفقاً لارجة معرفتهم بالأشطة الزراعية لمر اقبـة الانطلاق للتنمية و التعاون.

\begin{tabular}{|c|c|c|c|c|c|}
\hline \multicolumn{2}{|c|}{ ע } & \multicolumn{2}{|c|}{ 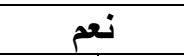 } & \multirow{2}{*}{ الأنشطــــة الزراعية } & \multirow[b]{2}{*}{ b } \\
\hline$\%$ & عدد & $\%$ & عدد & & \\
\hline $\mathrm{V}, \mathrm{V}$ & 0 & $94, r$ & 7. & الإشر اف الفنى و المالى على الجمعيات التعاونية الزر اعية بالقرية. & 1 \\
\hline $1 \pi, \wedge$ & 9 & $\Delta\urcorner, Y$ & 07 & توفير الميكنة الزراعية اللازمة فى المواعيد المناسبة. & r \\
\hline 17,9 & 11 & $\wedge r, 1$ & $0 \leqslant$ & توفير مستلزمات الإنتاج الزر اعى للخريجين بالقرية. & $r$ \\
\hline 11,0 & IT & 11,0 & or & تتوجيه وتدعيم أجهزة الجمعيات التعاونية الزر اعية بالقرية. & $\varepsilon$ \\
\hline Y1,0 & $1 \varepsilon$ & $\vee \wedge, 0$ & 01 & متابعة تتفيذ المنتفعين بالأر اضى الجديدة للدورات الزر اعية. & 0 \\
\hline$r 7, Y$ & IV & $V T, \wedge$ & $\varepsilon \wedge$ & |الإشر اف على أعمال مقاو مة الأفات فى المنطقة. & 7 \\
\hline$r q, Y$ & 19 & $V \cdot, \wedge$ & $\varepsilon 7$ & المساعدة فى حل المشكلات الزر اعية التى تو اجه فئات الانتفاع بالقرية. & $\mathrm{V}$ \\
\hline$r \cdot, \wedge$ & $r \cdot$ & $79, Y$ & $\leqslant 0$ & بحثث وتحديد المشكلات الزر اعية التى تو اجه فئات الانتفاع بالقرية. & $\wedge$ \\
\hline $0 \cdot, \wedge$ & ru & $\sum 9, Y$ & rt & |الإشر اف و القيام بعمليات التسويق الزر اعى للحاصلات الزر اعية. & 9 \\
\hline or, , & ro & $\sum 7, r$ & $r$ r. & |الإشر اف و القيام بعمليات تسويق المنتجات الحيو انية. & $1 \cdot$ \\
\hline
\end{tabular}

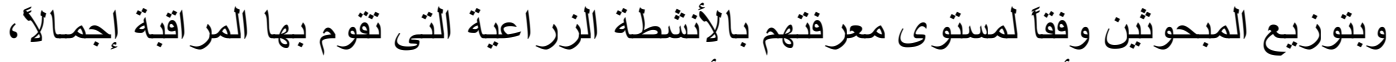

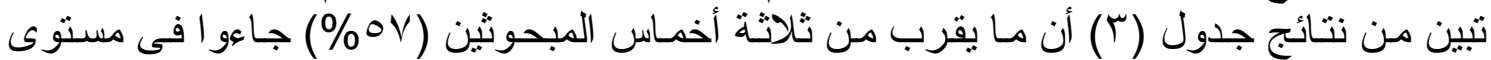

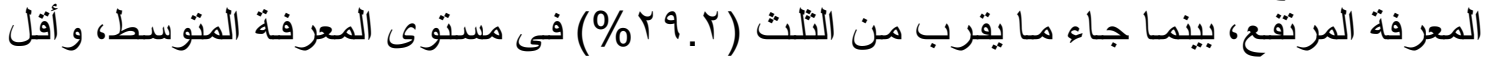

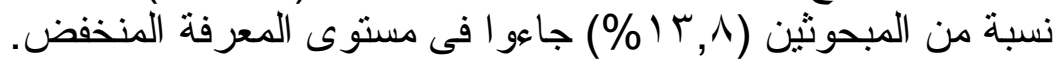

جدول r. توزيع المبحوثين من العاملين بالمر اقبة وفقاً لمستوى المعرفة بأنثطتها الزراعية إجمالاً.

\begin{tabular}{|c|c|c|}
\hline$\%$ & عدد & مستوى المعرفة \\
\hline $1 \%, \lambda$ & 9 & مستوى منخفض (1 - ب درجة) \\
\hline$r q, r$ & 19 & مستوى متوسط (§ ـا درجة) \\
\hline ov & $T \mathrm{~T}$ & مستوى مرتفع (V-• (1 درجة) \\
\hline $1 \ldots$ & 70 & جمالى \\
\hline
\end{tabular}

ثالثاً: درجة قيام المر اقبة بالأنشطة الزراعية:

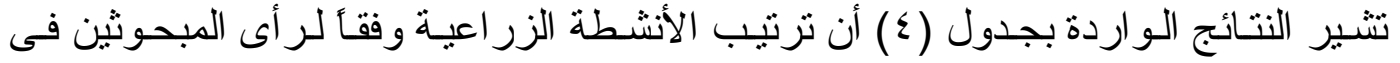

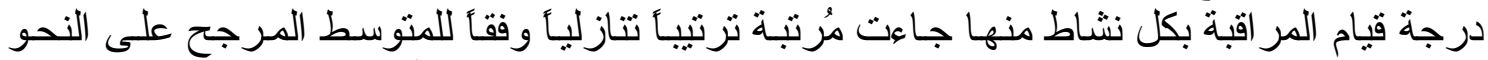

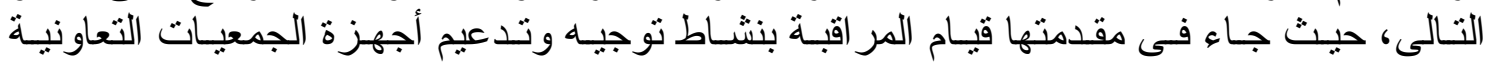

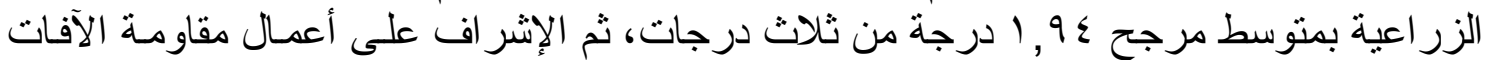

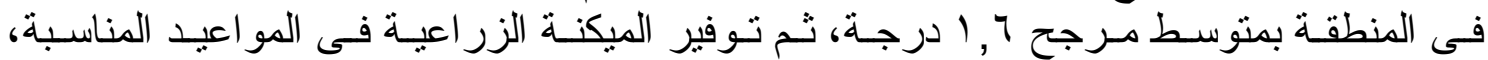

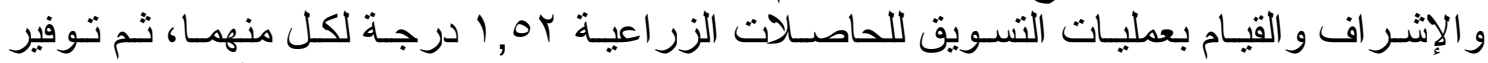

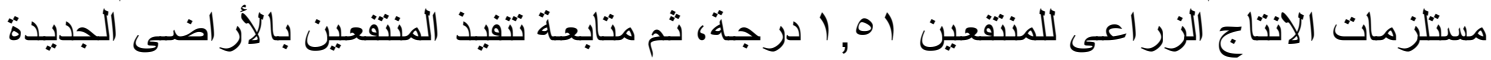

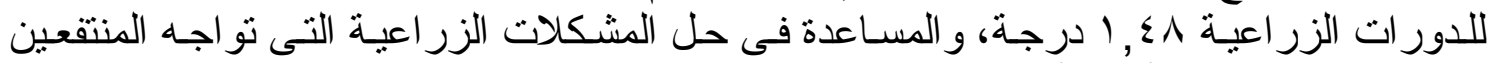

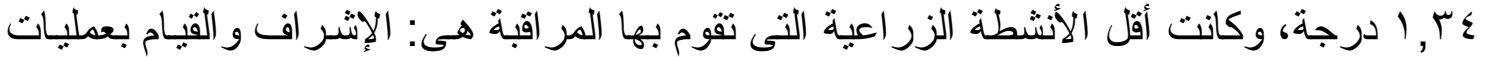

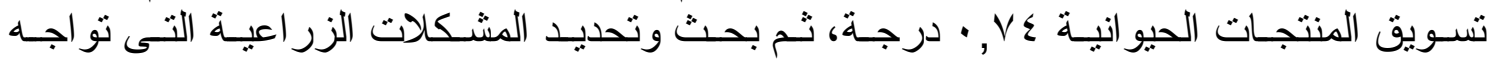
المنتفعين بالقرى الجديدة (V, • درجة. 
جذول ع ـ توزيع المبحوثين من العاملين بالمر اقبة وفقاً لارجة قيام المر اقبة بأنشطتها الزراعية.

\begin{tabular}{|c|c|c|c|c|c|c|c|c|c|c|}
\hline \multirow{3}{*}{ المرجح } & \multicolumn{8}{|c|}{ درجة القيام } & \multirow{3}{*}{ الأنشطــــة الزراعية } & \multirow{3}{*}{ م } \\
\hline & \multicolumn{2}{|c|}{ لا تقوم } & \multicolumn{2}{|c|}{ صغيرة } & \multicolumn{2}{|c|}{ متوسطة } & \multicolumn{2}{|c|}{ كبيرة } & & \\
\hline & $\%$ & عدد & $\%$ & عدد & $\%$ & عدد & $\%$ & عدد & & \\
\hline $1,9 \leq$ & $q . r$ & 7 & 17,9 & 11 & $\varepsilon \varepsilon, 7$ & Yq & $r q, r$ & 19 & |لزوجيه وتداعيم أجهزة الجمعيات التعاونية & 1 \\
\hline 1,7 & Y), 0 & $1 \varepsilon$ & 10,5 & 1. & $\varepsilon \varepsilon, 7$ & rq & 11,0 & IT & الإنطقة اف على أعمال مقاومة الأفات فى & $r$ \\
\hline $1,0 r$ & $r 7, r$ & IV & $10,\{$ & 1. & $r \wedge, 0$ & ro & $r$. & $\pi$ & 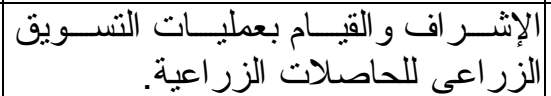 & $r$ \\
\hline $1,0 r$ & $r q, r$ & 19 & $1 \cdot, \wedge$ & V & $\Gamma \wedge, 0$ & ro & $r 1,0$ & $1 \varepsilon$ & 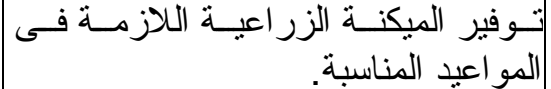 & $r$ \\
\hline 1,01 & $r 7, r$ & IV & 11,0 & Ir & 更 & rr & $r 1,0$ & $1 \leq$ & 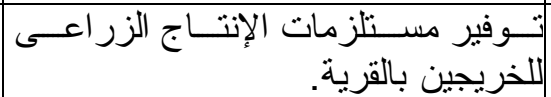 & $\varepsilon$ \\
\hline $1, \leqslant \wedge$ & $r \uparrow, r$ & IV & 17,9 & 11 & $\varepsilon$. & YT & 17,9 & 11 & للدابعة تتفيذ المنتفعين بالأر اضى الجديدة & 0 \\
\hline $1, r \varepsilon$ & $r \cdot, \wedge$ & $r$. & Y), 0 & $1 \varepsilon$ & $r \cdot, \wedge$ & $r$. & 17,9 & 11 & 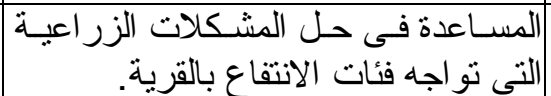 & 7 \\
\hline $1, \cdot 7$ & $\leqslant 1,0$ & $T V$ & 17,9 & 11 & $\Gamma_{0}, \Gamma$ & rT & $7, r$ & $\varepsilon$ & 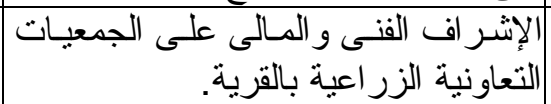 & V \\
\hline$\cdot, \mathrm{V} \varepsilon$ & $0 \wedge, 0$ & rᄉ & 17,9 & 11 & 17,9 & 11 & $V, V$ & 0 & 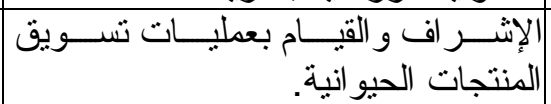 & $\wedge$ \\
\hline$\cdot, \times 1$ & \1, & $\varepsilon$. & $1 \Gamma, \wedge$ & 9 & 17,9 & 11 & $V, V$ & 0 & 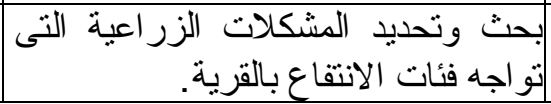 & 9 \\
\hline $1, r \varepsilon$ & & & & & & & & & b. ت & \\
\hline
\end{tabular}

وبتوزيع المبحوثنين وفقاً لر أيهم فى مستوى قيام مر اقبة الانطـلاق للتتمية و التعاون بالأنشطة

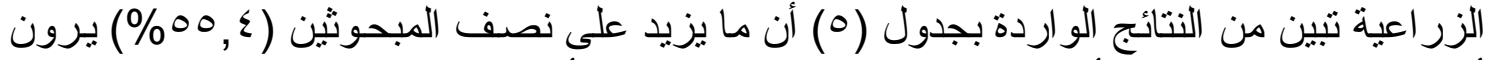

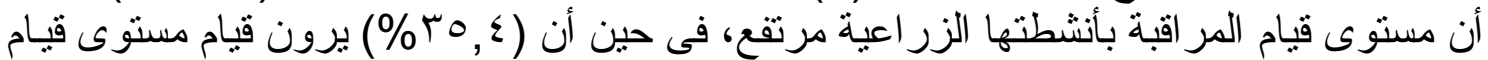

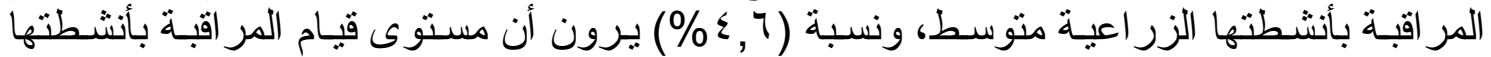

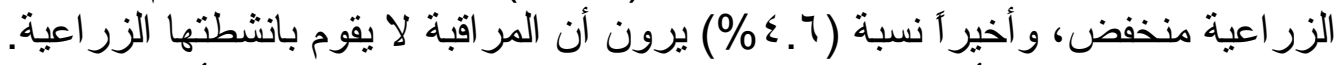

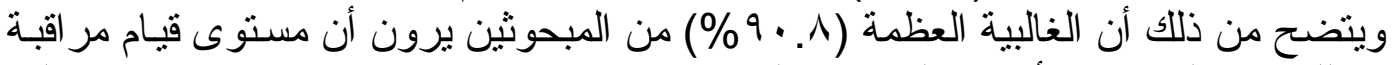

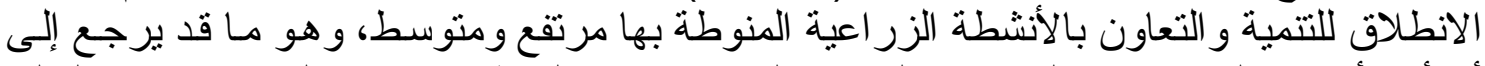

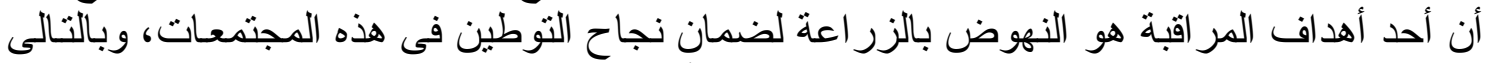

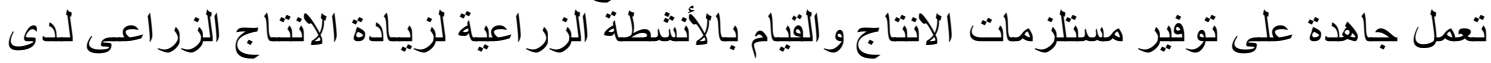

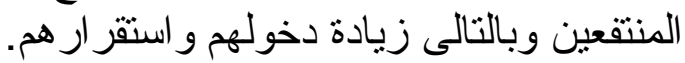

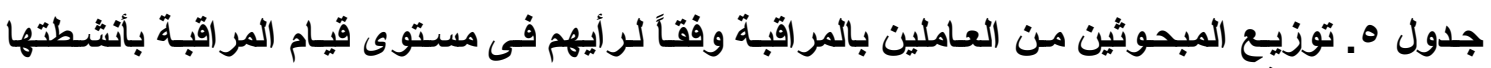
الزر اعية.

\begin{tabular}{|c|c|c|}
\hline$\%$ & عدد & مستوى قيام المراقبة بأنشطتها \\
\hline$\varepsilon, 7$ & $r$ & لا تقـــــــــم (صفر درجة) \\
\hline$\varepsilon, 7$ & $r$ & مستوى منخفض ( ( ـ9 درجة) \\
\hline ro,, & $r \mu$ & مستوى متوسط (· ( _N ( درجة) \\
\hline 00,2 & ry & 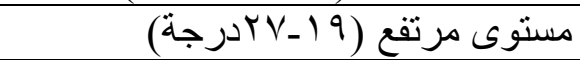 \\
\hline
\end{tabular}


رابعاً: رأى المبحوثين فى تواجد المشكلات الزراعية:

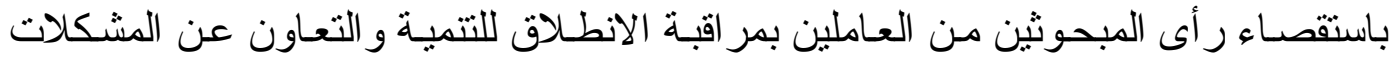

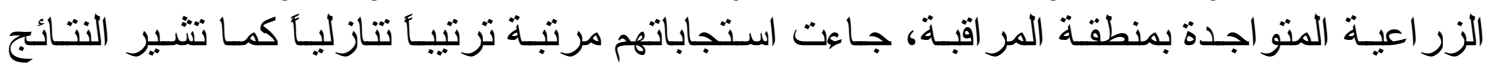

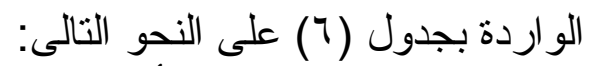

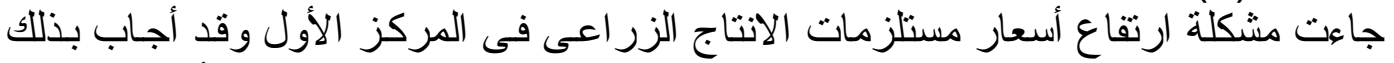

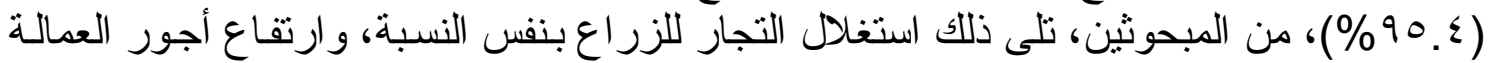

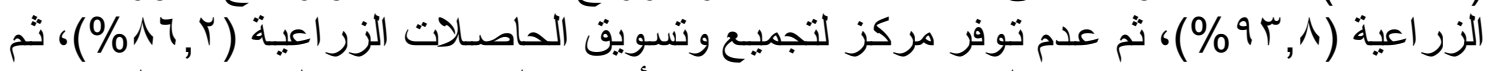

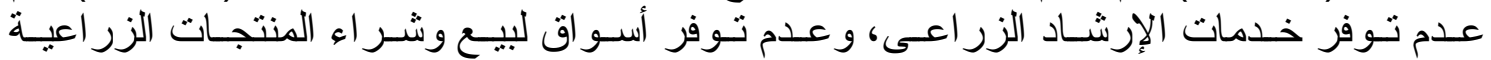

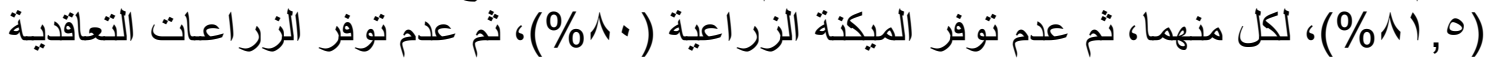

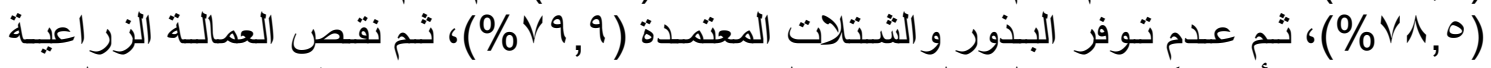

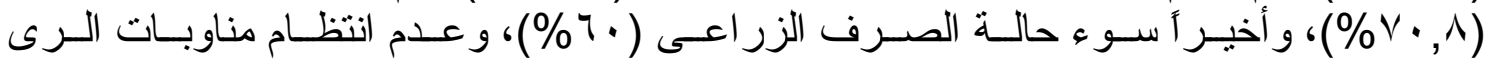

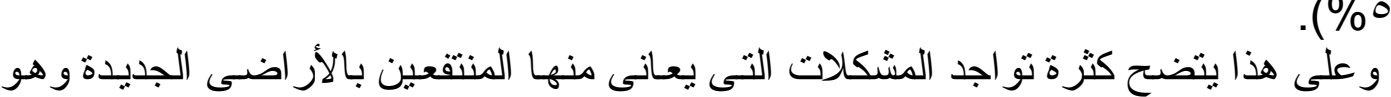

$$
(\% \circ 1,0)
$$

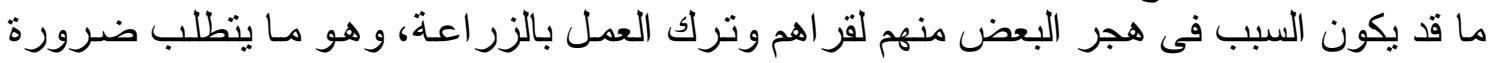

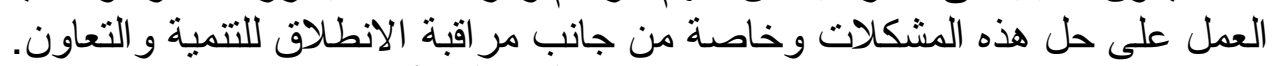

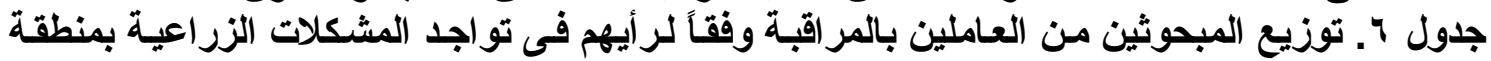
الار اسة.

\begin{tabular}{|c|c|c|c|c|c|c|}
\hline \multirow{3}{*}{ الترتيب } & \multicolumn{4}{|c|}{ التواجد } & \multirow{3}{*}{ المشكلات الزراعية المية } & \multirow{3}{*}{ م } \\
\hline & \multicolumn{2}{|c|}{ لا } & \multicolumn{2}{|c|}{ نعم } & & \\
\hline & $\%$ & عدد & $\%$ & عدد & & \\
\hline 1 & $\varepsilon, 7$ & $r$ & 90,5 & Tr & | استغلال التجار للزراع. & 1 \\
\hline 1 & $\varepsilon, 7$ & $r$ & $90, \xi$ & $4 T$ & |إرتفاع أسعار مستلزمات الإنتاج الزراعى. & $r$ \\
\hline$r$ & $7, r$ & $\varepsilon$ & $9 \pi, \wedge$ & 71 & |رارتفاع أجور العمالة الزر اعية. & $\mu$ \\
\hline$r$ & $1 T, \wedge$ & 9 & $\Lambda \neg, Y$ & 07 & عدم توفر مركز لتجميع وتسويق الحاصلات الزراعية. & $\varepsilon$ \\
\hline$\varepsilon$ & 10,2 & 1 . & $\wedge \varepsilon, 7$ & 00 & صعوبة عملية التسويق للمحاصيل الزر اعية. & 0 \\
\hline 0 & 11,0 & IY & 11,0 & or & نقص حصة الأسمدة المصروفة. & 7 \\
\hline 0 & 11,0 & Ir & 1,0 & or & |عدم توفير الأسمدة البوتاسية والفوسفاتية. & $\mathrm{V}$ \\
\hline 0 & 11,0 & IY & 11,0 & or & |عدم توفر خدمات الإرشاد الزر اعى. & $\wedge$ \\
\hline 0 & 11,0 & IY & 11,0 & or & عدم توفر أسواق لبيع وشر اء المنتجات الزر اعية. & 9 \\
\hline 7 & $r \cdot$ & 14 & $\Lambda$. & or & عدم توفر الميكنة الزر اعية. & $1 \cdot$ \\
\hline $\mathrm{V}$ & Y),0 & $1 \varepsilon$ & $\vee \wedge, 0$ & 01 & |عدم توفر الزر اعات التعاقدية. & 11 \\
\hline$\Lambda$ & $r T, 1$ & 10 & $V 7,9$ & 0 . & نقص البذور و التقاوى و الثتلات المعتمدة. & Ir \\
\hline 9 & $r q, r$ & 19 & $v \cdot, \wedge$ & $\leqslant 7$ & |نقص العمالة الزر اعية . & $1 \pi$ \\
\hline $1 \cdot$ & $\varepsilon$. & r7 & 7. & rq & سوء حالة الصرف الزراعى. & $1 \leqslant$ \\
\hline 11 & $\leqslant 1,0$ & TV & $0 \wedge, 0$ & rᄉ & عدم انتظام مناوبات مياه الرى. & 10 \\
\hline
\end{tabular}

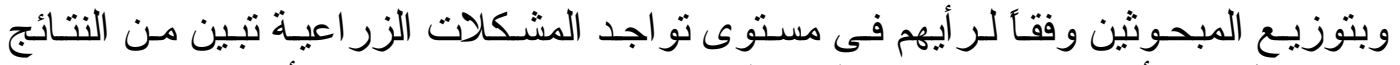

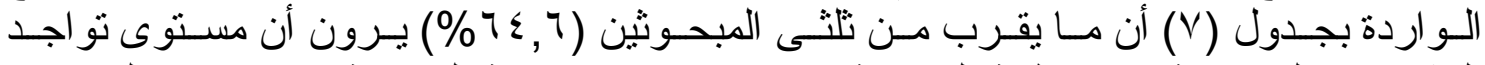

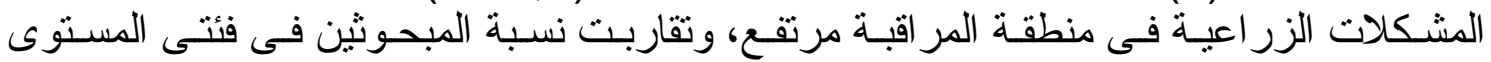
المتوسط و المنخفض، حيث بلغت (1) (1\%)، و (9. . 1 (1\%)، على الترنيب. 
جدول V. توزيع المبحوثين من العاملين بالمر اقبة وفقاً لر أيهم فى مستوى تواجد المشكلات الزراعية

المدروسة إجمالاً.

\begin{tabular}{|c|c|c|}
\hline$\%$ & عدد & مستوى تواجد المشكلات الزراعية \\
\hline 17,9 & 11 & مستوى منخفض ( ـ ـ درجة) \\
\hline 11,0 & IT & مستوى متوسط (ך- • ( درجة) \\
\hline $7 \leqslant, 7$ & $\varepsilon r$ & مستوى مرتفع (' (10 ا درجة) \\
\hline
\end{tabular}

خامساً: رأى المبحوثين فى درجة قيام المر اقبة بالمساعدة فى حل المشكلات الزراعية:

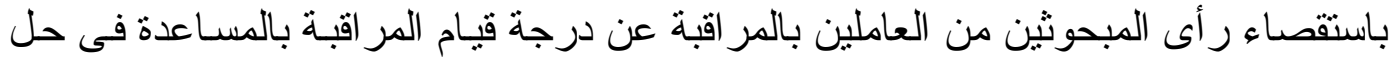

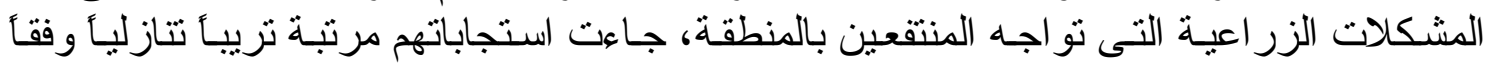

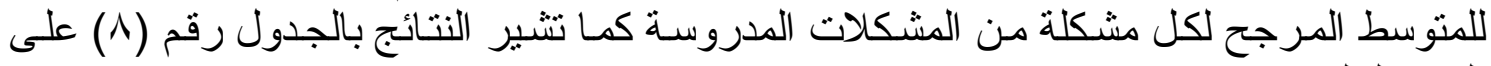

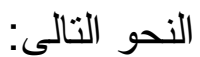

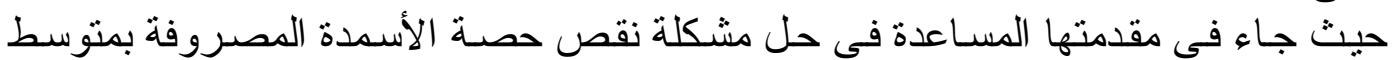

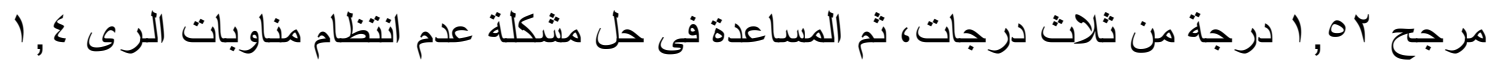

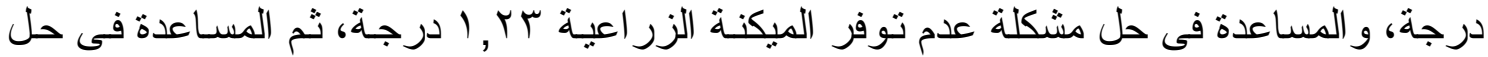

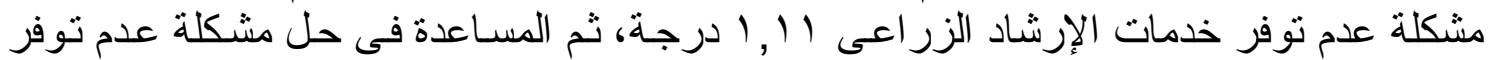

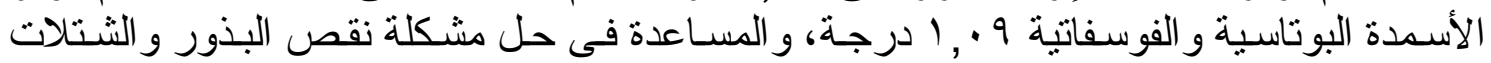

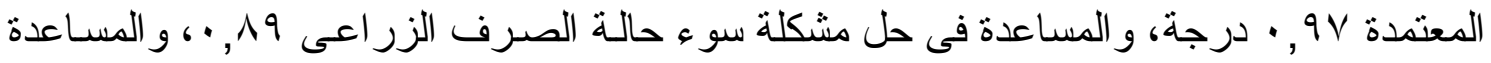

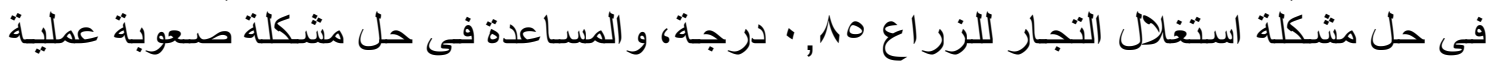

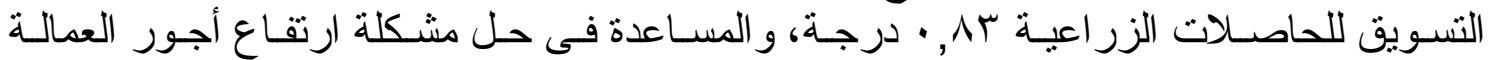

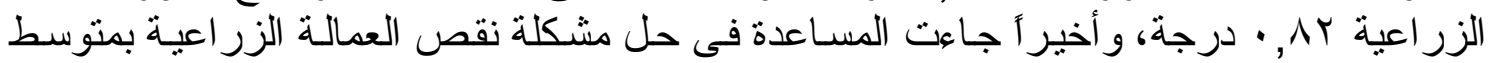

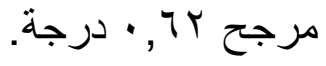


Assiut J. Agric. Sci., 51 (1) 2020 (217-233)

ISSN: 1110-0486

Website:www.aun.edu.eg/faculty_agriculture/journals_issues_form.php E-mail: ajas@aun.edu.eg

جدول ^. توزيع المبحوثين من العاملين بالمر اقبة وفقاً لـ أيهم فى درجة قيام المر اقبة بالمساعدة فى

حل المشكلات الزراعية المدروسة.

\begin{tabular}{|c|c|c|c|c|c|c|c|c|c|c|c|}
\hline \multirow{3}{*}{ 沀 } & \multirow{3}{*}{ 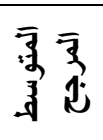 } & \multicolumn{8}{|c|}{ درجة قيام المراقبة بالمساعدة فى الحل } & \multirow{3}{*}{ المشكلات الزراعية } & \multirow{3}{*}{ م } \\
\hline & & \multicolumn{2}{|c|}{ لاتقوم } & \multicolumn{2}{|c|}{ صغيرة } & \multicolumn{2}{|c|}{ |متوسطة } & \multicolumn{2}{|c|}{ كبيزة } & & \\
\hline & & $\%$ & عدد & $\%$ & |عدد & $\%$ & عدد & $\%$ & عدد & & \\
\hline 1 & 1,04 & $T V, V$ & 11 & IT,r & $\Lambda$ & $\varepsilon$ & rT & r. & $\pi$ & |نقص حصة الأسمدة المصروفة. & 1 \\
\hline r & $1, \varepsilon$. & $r, \wedge$ & Tr & $1 \cdot, \wedge$ & $\mathrm{V}$ & $r q, 9$ & $T \Sigma$ & 11,0 & IT & عدم انتظام مناوبات مياه الرى. & $r$ \\
\hline$r$ & $1, r \mu$ & $r, \Lambda$ & rt & $r 1,0$ & $\varepsilon$ & $r, r$ & YI & Ir, & $\Lambda$ & عدم توفر الميكنة الزر اعية. & $r$ \\
\hline$\varepsilon$ & 1,11 & $0, r$ & Yr & $r \leqslant, 7$ & 7 & $r, \wedge$ & YY & $7, Y$ & & عدم توفر خدمات الإرشاد الزر اعى. & $\varepsilon$ \\
\hline 0 & $1, \cdot 9$ & $\leqslant v, v$ & r & $7, Y$ & $\varepsilon$ & $r 0, r$ & $r T$ & $1 \cdot, 1$ & $\mathrm{v}$ & الزارتفاع. & ๑ \\
\hline 0 & $1, \cdot 9$ & $\varepsilon, 7$ & rq & $\bar{T}, r$ & $\Lambda$ & 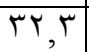 & Y) & $1 \cdot, 1$ & $\mathrm{v}$ & عدم توفير الأسمدة البوتاسية و الفوسفاتية. & 7 \\
\hline 7 & $\cdot, 9 V$ & Or, & $\Gamma \varepsilon$ & $7, Y$ & \{ & rr, & TY & $\mathrm{v}, \mathrm{V}$ & 0 & نقص البذور و التقاوى و الثنتلات المعتمدة & $\mathrm{v}$ \\
\hline $\mathrm{V}$ & $\cdot, \wedge 9$ & $\varepsilon q, r$ & rY & $10, \varepsilon$ & - & $r, r$ & Y) & 4,1 & r & سوء حالة الصرف الزر اعى. & $\Lambda$ \\
\hline $\mathrm{V}$ & $\cdot, \wedge 9$ & or, r & $r \varepsilon$ & 17,9 & 11 & $r$. & 14 & $1 \cdot, 1$ & V & عدم توفر الزر اعات التعاقدية. & 9 \\
\hline$\wedge$ & $\cdot, \wedge 0$ & 01,0 & $r \wedge$ & $9, Y$ & 7 & YI,0 & $1 \varepsilon$ & $1 \cdot, 1$ & V & استغلال التجار للزراع. & 1. \\
\hline 9 & 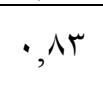 & 07,9 & rV & $1 \pi, \Lambda$ & 9 & 11,0 & IT & $1 \cdot, \wedge$ & $\mathrm{V}$ & الزراعبة. عملية التسويق للمحاصيل & \\
\hline 1. & $\cdot, \wedge r$ &, 0 & rA & $T, r$ & $\Lambda$ & 11,0 & IT & $1 \cdot, 1$ & V & |ارتفاع أجور العمالة الزر اعية. & Ir \\
\hline 11 & $\cdot$, & $0, \varepsilon$ & r & $10, \varepsilon$ & 1. & r. & $\pi$ & $\mathrm{v}, \mathrm{V}$ & 0 & 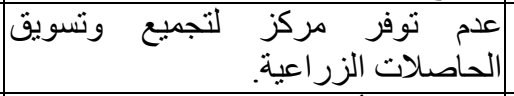 & ir \\
\hline ir & $\cdot, \mathrm{V}_{0}$ & $\pi$ & $\varepsilon$ & $q, r$ & 7 & 17,9 & 11 & $1 \cdot, \wedge$ & $v$ & الزراعية. & $1 \varepsilon$ \\
\hline$\pi$ & $\cdot, 7 T$ & 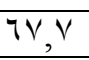 & $\varepsilon \varepsilon$ & $\overline{v, V}$ & 0 & $r$ & 14 & $\varepsilon, 7$ & 1 & نقص العمالة الزر اعية. & 10 \\
\hline
\end{tabular}

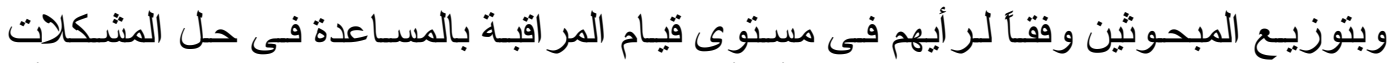

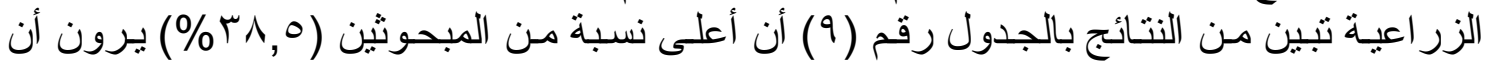

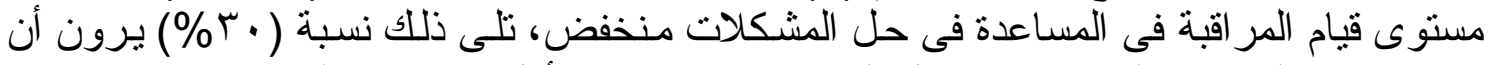

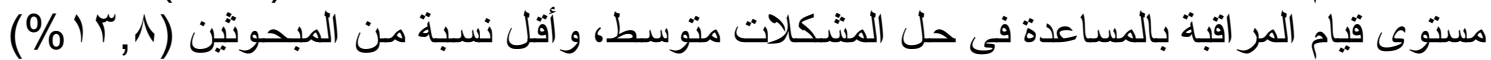

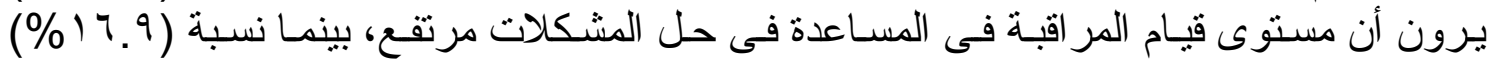

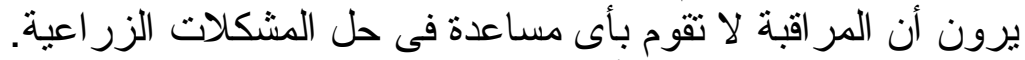

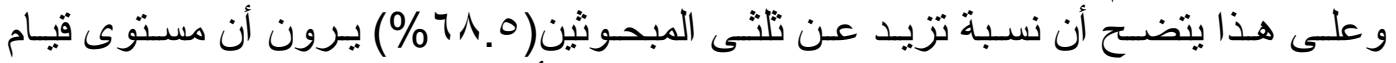

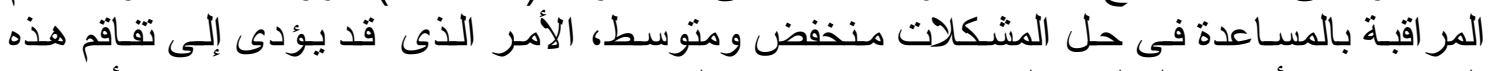

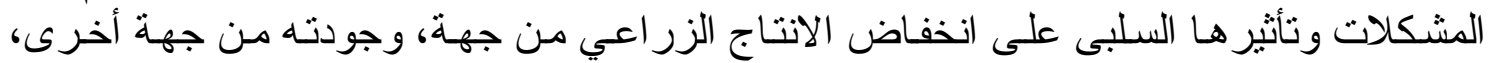

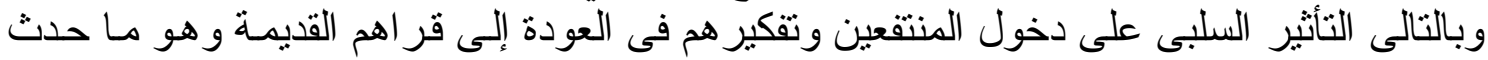

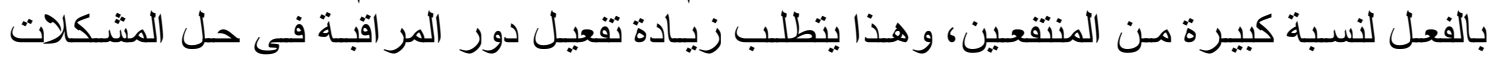

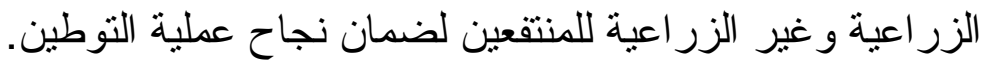

جدول 9 ـ توزيع المبحوثين من العاملين بالمر اقبة وفقاً لر أيهم فى مستوى قيام المر اقبة بالمسـاعدة فى

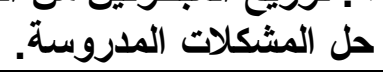

\begin{tabular}{|c|c|c|}
\hline$\%$ & عدد & مستوى القيام بالمساعدة فى حل المشكلات \\
\hline 17,9 & 11 & لا تقــــوم (صفر درجة) \\
\hline$r \wedge, 0$ & ro & مستوى منخفض (1 - 10 درجة) \\
\hline$r \cdot, \wedge$ & $r \cdot$ & مستوى منوسط (7 ( - · ب درجة) \\
\hline $1 \pi, \wedge$ & 9 & مستوى مرتفع (اس_0؛ درجة) \\
\hline
\end{tabular}




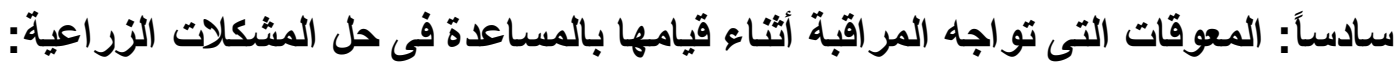

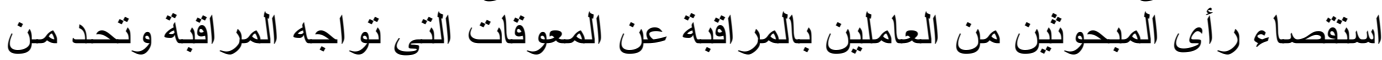

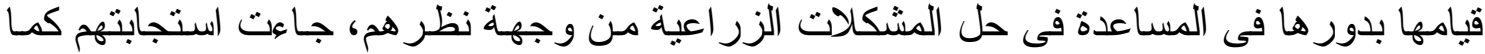
تتشير النتائج بالجدول رقم (· • (1) على النحو النتالى:

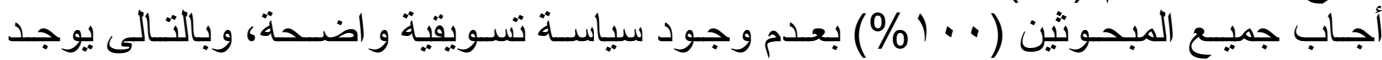

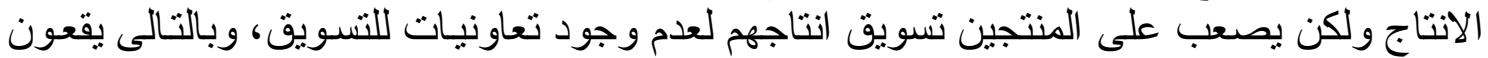

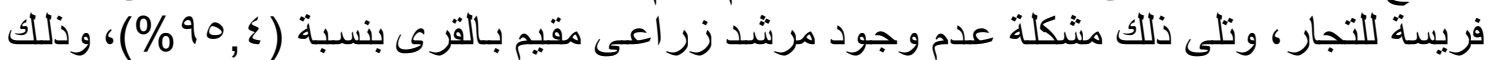

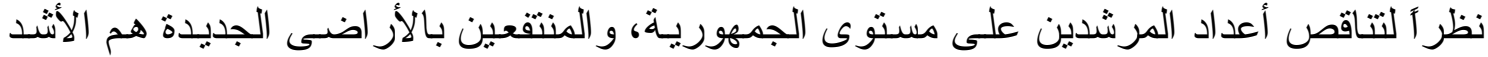

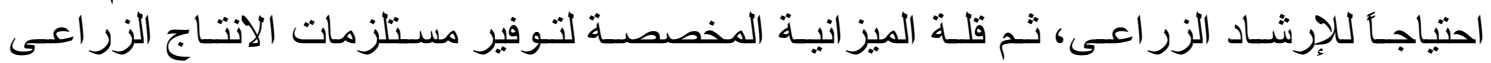

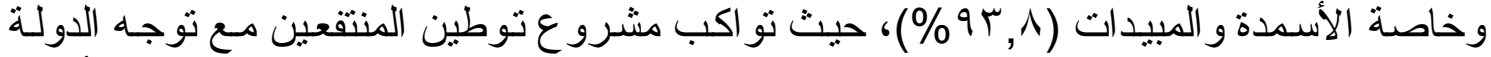

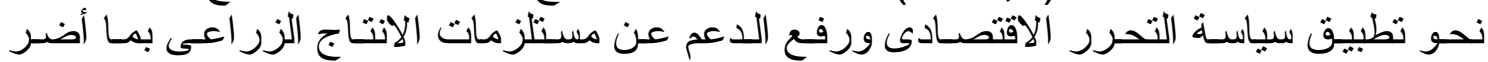

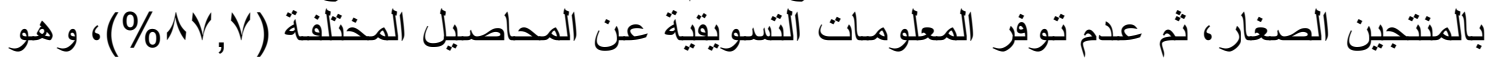

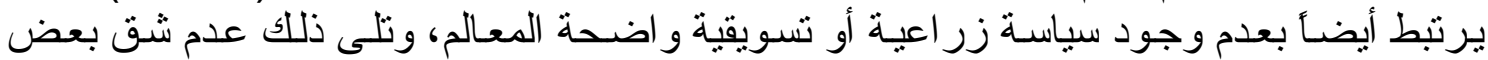

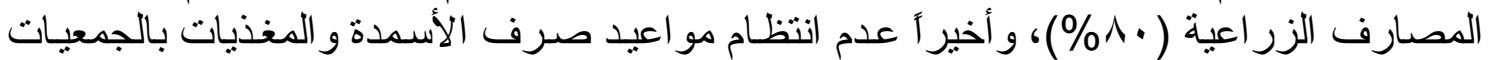

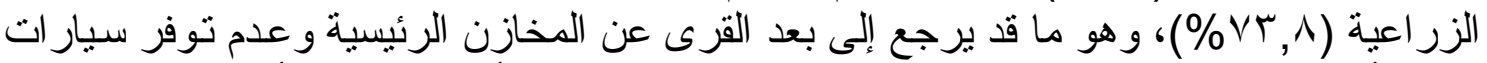

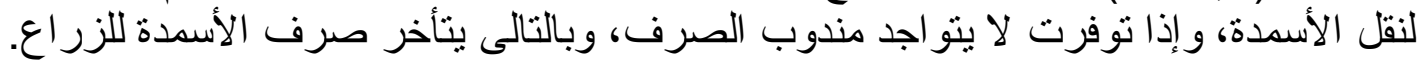

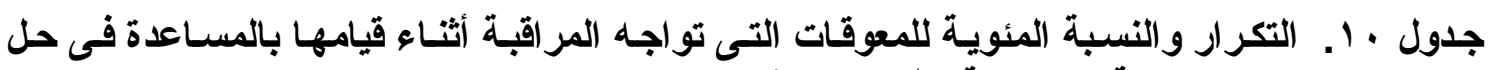
$10=0$ المشكلات الزراعية من وجهة نظر المبحوثين المبن

\begin{tabular}{|c|c|c|c|c|}
\hline \multirow[t]{2}{*}{ الترتيب } & & & \multirow{2}{*}{ المعوقات } & \\
\hline & $\%$ & عدد & & p \\
\hline 1 & $1 \cdots$ & 70 & عدم وجود سياسة تسويقية و اضحة. & 1 \\
\hline r & $90, \xi$ & $7 Y$ & عدم وجود مرشد زر اعى مقيم بالقرى. & r \\
\hline r & $94, \wedge$ & 71 & قلأسمدة الميز النية المبيدات. & $\mu$ \\
\hline$\varepsilon$ & A. & or & عدم شق بعض المصارف الزر اعية. & $\varepsilon$ \\
\hline & $\Lambda \vee, V$ & OV & عدم تو افر المعلومات التسويقية عن المحاصيل المختلفة. & 0 \\
\hline 0 & $v r, \wedge$ & $\Sigma \wedge$ & عدم انتظام مو اعيد صرف الأسمدة و المغذيات بالجمعيات الزر اعية. & 7 \\
\hline
\end{tabular}

سابعاً: مقترحات التظلب على المعوقات التى تواجه المراقبة أثناء قيامها بالمساعدة فى حل المشكلات الزر اعية الماتية

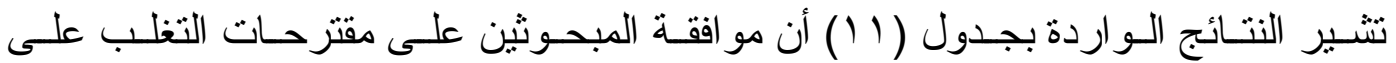

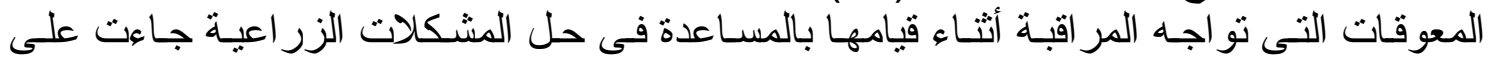

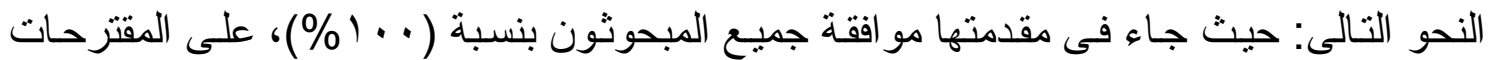

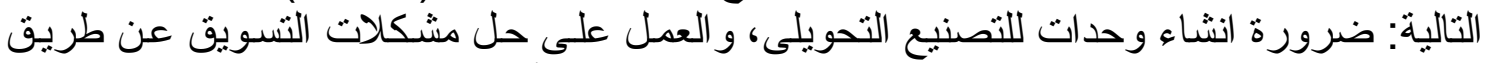

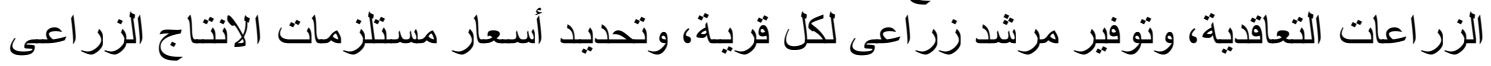

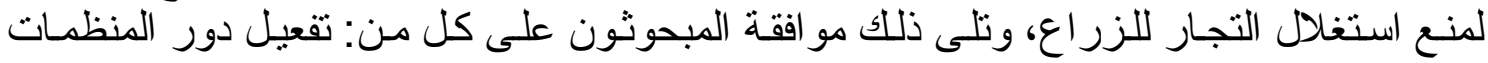

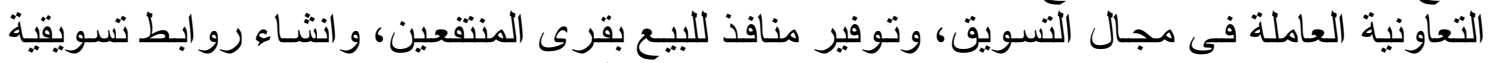

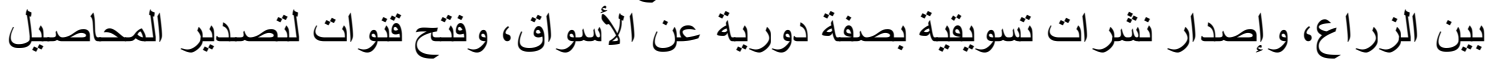

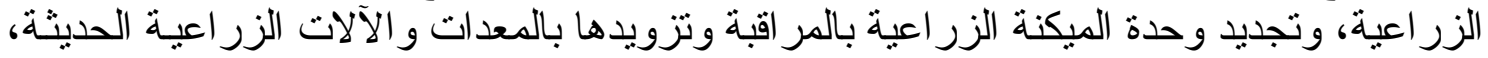

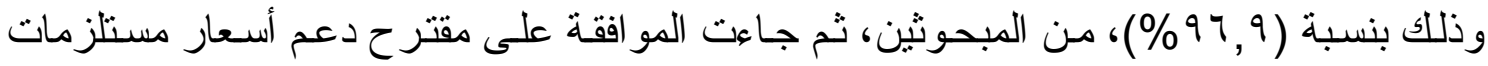


Website:www.aun.edu.eg/faculty_agriculture/journals_issues_form.phpE-mail:ajas@aun.edu.eg

الانتاج الزر اعى المختلفة بنسبة (ع,90\%)، و أخير أزيـادة منسوب ميـاه الرى بالتبطين بنسبة

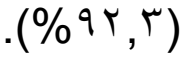

و على هذا يتضح تعدد وتتو ع مقترحات المبحوثين للتغلب على المعوقات التى التى تقابل المر اقبـة

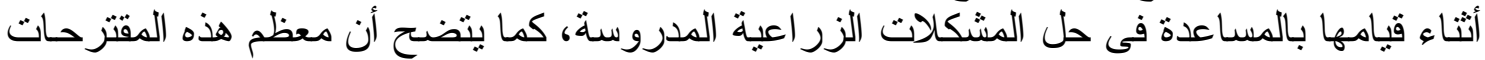

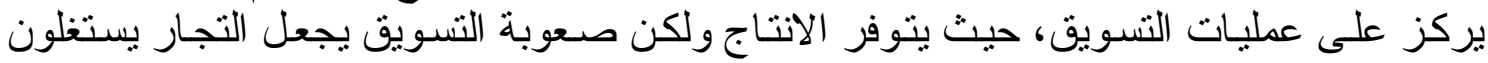
المنتجين لعدم توفر القدر ات التسويقية لديهم.

جدول 11 التكرار و النسبة المئوية لمقترحات التظلب على المعوقات التى تقابل المر اقبـة أثتاء قيامها

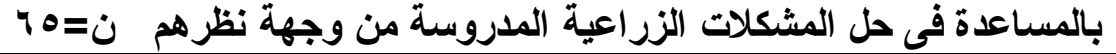

\begin{tabular}{|c|c|c|c|c|}
\hline \multirow[t]{2}{*}{ الترتيب } & & & \multirow{2}{*}{ المقترحات } & \multirow[b]{2}{*}{ p } \\
\hline & $\%$ & عدد & & \\
\hline 1 & $1 \cdots$ & 70 & ضرورة انشاء وحدات للتصنيع التحويلى. & 1 \\
\hline 1 & $1 \cdots$ & 70 & العمل على حل مشكلات التسويق عن طريق الزر اعات التعاقدية. & r \\
\hline 1 & $1 \cdots$ & 70 & ضرورة وجود مرشد زر اعى حكومى فى القرية. & $r$ \\
\hline 1 & $1 \cdots$ & 70 & تحديد أسعار مستلزمات الإنتاج الزراعى لمنع استغلال التجار للزراع. & $\varepsilon$ \\
\hline r & 97,9 & זד & التسعيل دور المنظمات التعاونية العاملة فى مجال التسويق وخاصة الجمعية & 0 \\
\hline r & 97,9 & $7 \pi$ & توفير منافذ للبيع بقرى الخريجين. & 7 \\
\hline Y & 97,9 & 74 & انشاء رو ابط تسويقية بين الزراع لتسويق منتجاتهم. & $\mathrm{V}$ \\
\hline r & 97,9 & 74 & اصدار نشرات تسويقية بصفة دورية عن الأسواق. & $\Lambda$ \\
\hline Y & 97,9 & 74 & فتح قنو ات مختلفة لتصدير المحاصيل الزر اعية. & 9 \\
\hline r & 97,9 & זיד & تجديد وحدة الميكنة الزر اعية بالمر اقبة وتزويد ها الجدي بمعدات و آلات جديدة تلائم & 1 . \\
\hline$r$ & 90,5 & $7 r$ & دعم أسعار مستلزمات الإنتاج الزراعى المختلفة. & 11 \\
\hline$\varepsilon$ & $94, r$ & 7. & زيادة منسوب مياه الرى بالتبطين. & Ir \\
\hline
\end{tabular}

ثامناً: العلاقة بين المتغيرات المستقلة المدروسة للمبحوثين، وبين راى المبحوثين فى درجة

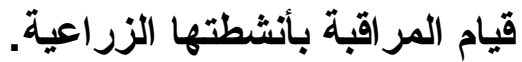

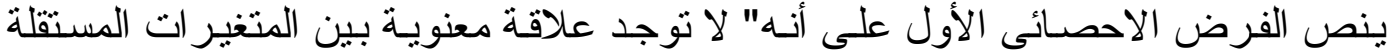

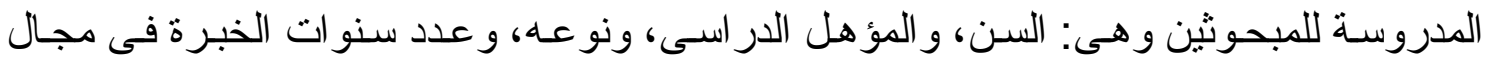

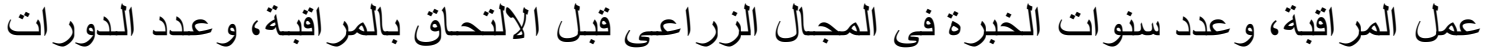

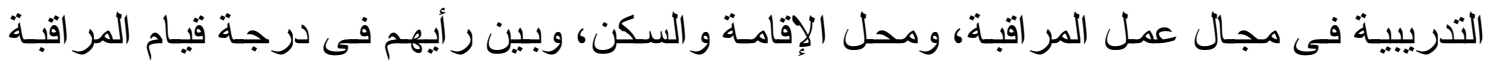

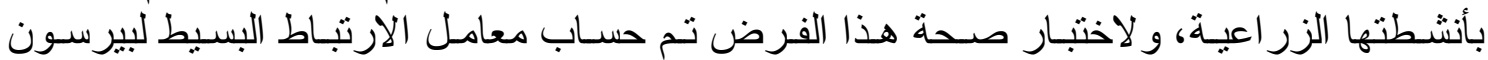

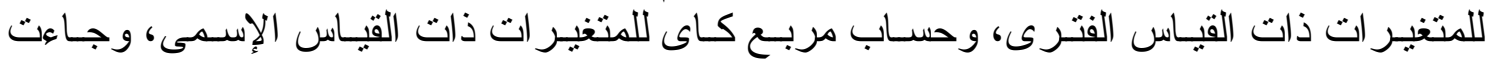

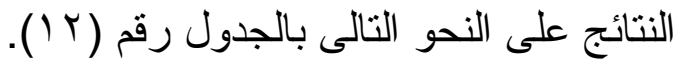

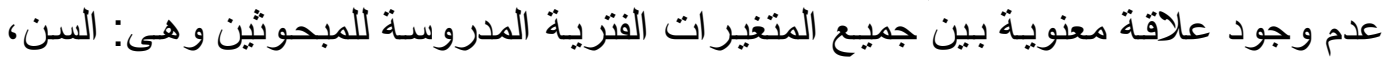

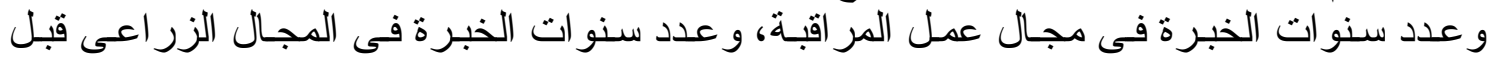

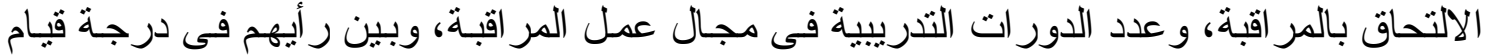

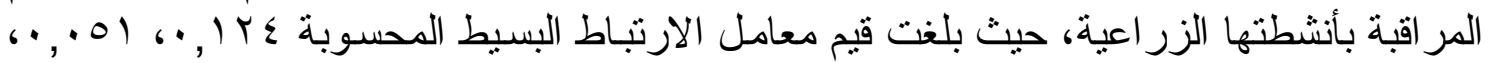

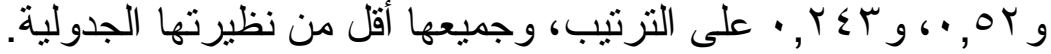

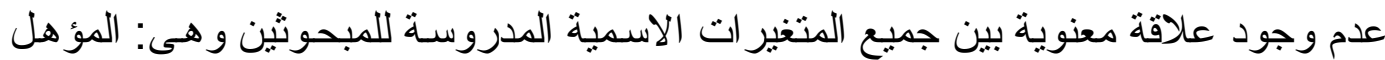

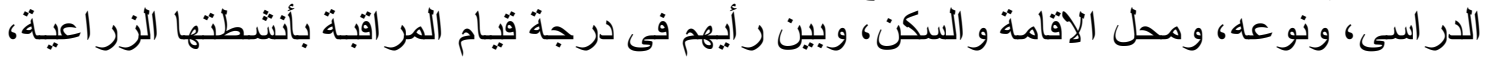

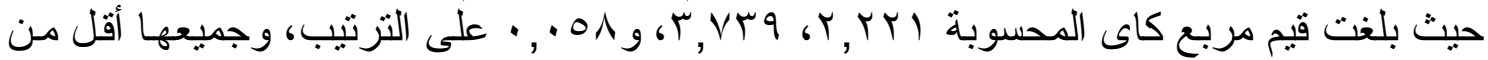

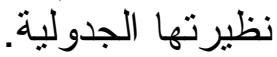




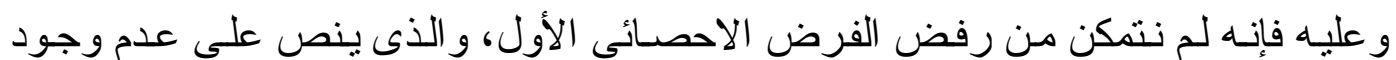

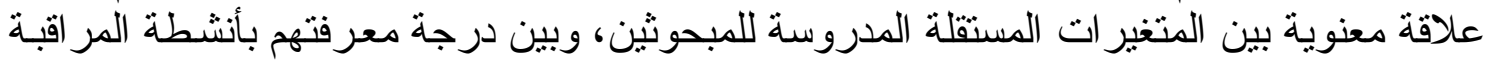

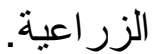

جـدول ب ا ـ قيم معامـل الارتبـاط البسـيط ومربـع كـاى للعلاقــة بـين المتغيـرات المسـتقلة المدروســة للمبحوثين ودرجة معرفتهم بأنشطة المر اقبة الزبية الزراعية.

\begin{tabular}{|c|c|c|c|}
\hline \multicolumn{2}{|c|}{ درجة معرفة المبحوثين بأنشطة المراقبة الزر اعية } & \multirow[b]{2}{*}{ المتغير ات المستقلة } & \multirow[b]{2}{*}{ ? } \\
\hline قيمة مربع كاى & قيمة معامل الارتباط البسيط & & \\
\hline & $\cdot, 1 Y \leq \quad-$ & 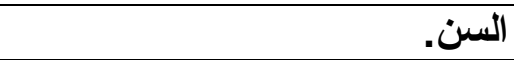 & 1 \\
\hline & $\cdot, .01 \quad-$ & عدد سنوات الخبرة داخل المر اقبة. & $r$ \\
\hline & $\cdot$, OY & عدد سنوات الخبرة خارج المراقبة. & $r$ \\
\hline & $\cdot, r \leqslant T$ & عدد الدورات التدريبية. & $\varepsilon$ \\
\hline r,YY) & & المؤهل الار اسى. & 0 \\
\hline$r, v r q$ & & نوع المؤهل الدراسى. & 7 \\
\hline$\cdot, .01$ & & محل الإقامةٌ و السكن. & V \\
\hline
\end{tabular}

تاسعاً: العلاقة بين المتغيرات المستقة المدروسة للمبحوثين، وبين رأيهم فى درجة قيام المراقبة بالمساعدة في حل المشكلات الزئ المراعية المدروسة.

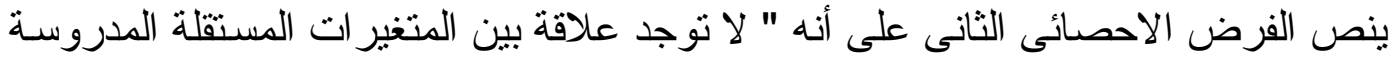

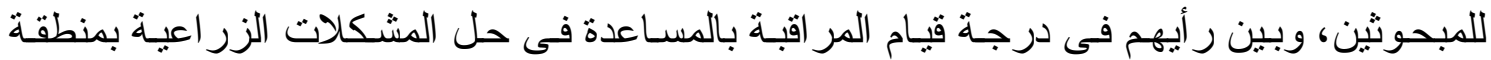

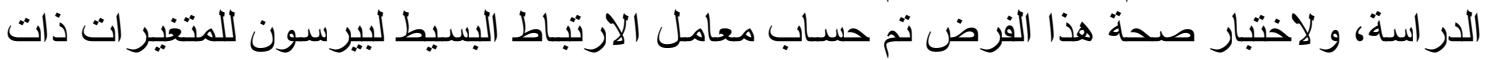

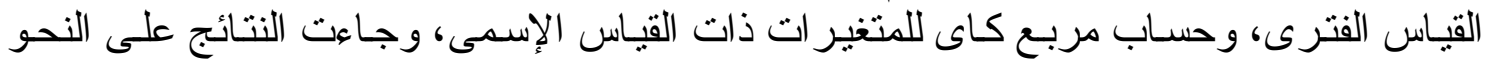

النالى جدول رقم (T)

وجود علاقة طردية بين متغير عدد الدور ات التدريبية، وبين رأى المبحوثين فى درجة قيام

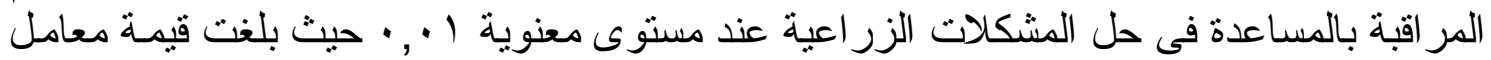

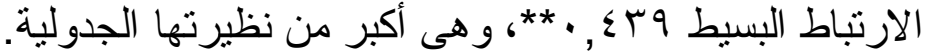

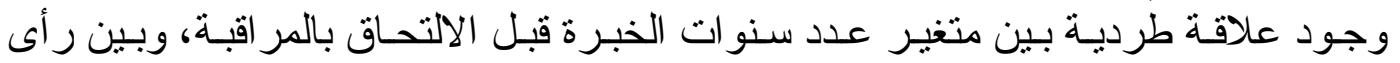

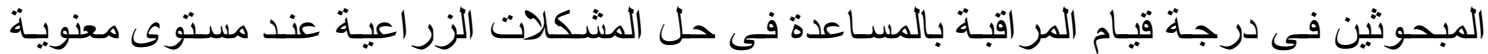

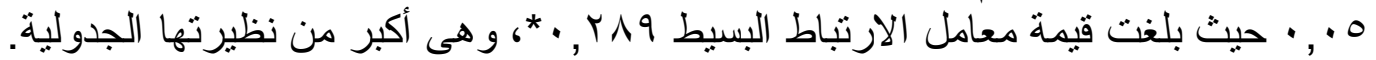

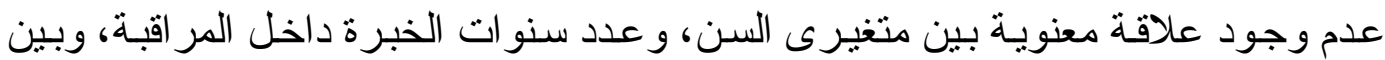

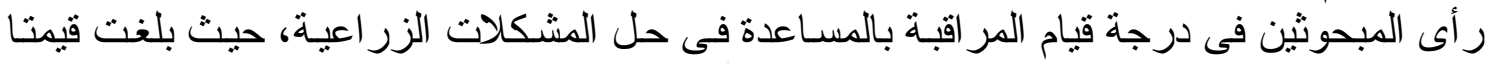

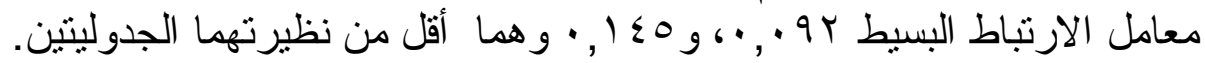

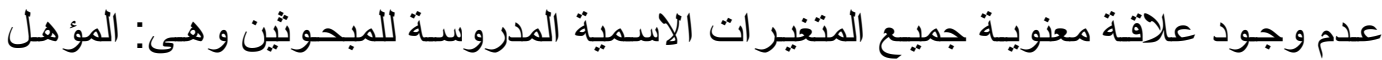

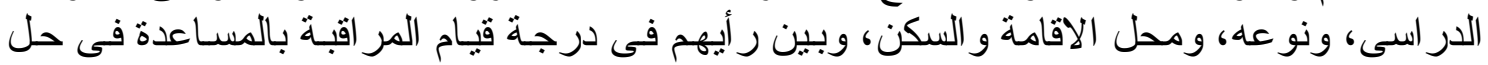

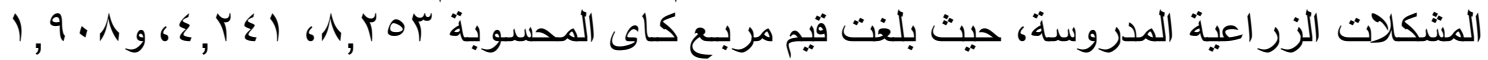

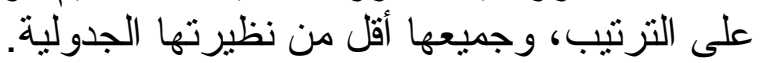

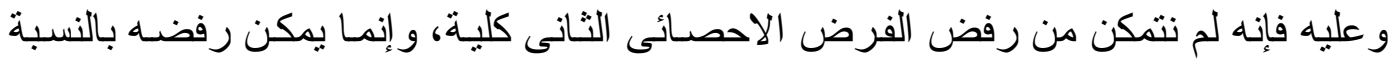

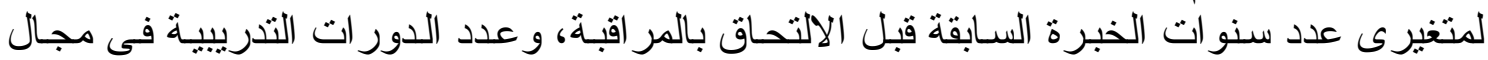

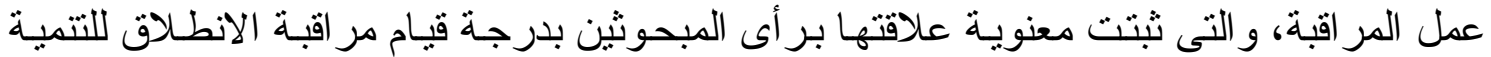
و التعاون بالمساعدة فى حل المشكلات الزر اعية المدروسة، أى انه كلماز ادت ادت عدد سنو ات ات الخبرة 

السابقة خارج المر اقبة و عدد الدور ات التدريبية التى حصل عليها المبحوثون، كلما كان ر أيهم فى الئى درجة قيام المر اقبة بالمساعدة فى حل المشكلات الزر اعية اليجابياً.

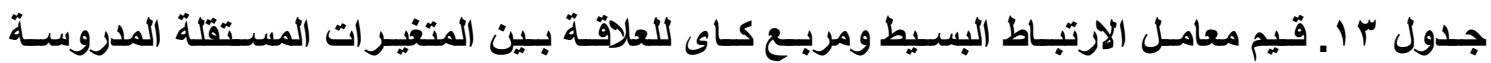

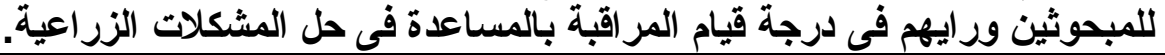

\begin{tabular}{|c|c|c|c|}
\hline \multicolumn{2}{|c|}{ درجة قيام المر اقبّة بالمساعدة فى حل المشكلات الزراعية } & \multirow[b]{2}{*}{ المتغير ات المستقلة } & \multirow[b]{2}{*}{ p } \\
\hline 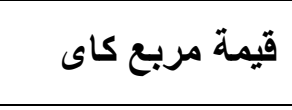 & قيمة معامل الارتباط البسيط & & \\
\hline & $\cdot, .95$ & السن. & 1 \\
\hline & $\cdot, 1 \leqslant 0$ & عدد سنوات الخبرة الاخخلية. & r \\
\hline & $*, r \wedge 9$ & عدد سنو ات الخبرة الخارجية. & $r$ \\
\hline & ${ }^{* *} \cdot, \varepsilon r q$ & عدد الدورات التدريبية. & $\varepsilon$ \\
\hline A, ror & & المؤهل الدراسى. & 0 \\
\hline$\varepsilon, r \leqslant 1$ & & نوع المؤهل الدراسى. & 7 \\
\hline $1,9 \cdot 1$ & & محل الإقامة و السكن. & $\mathrm{V}$ \\
\hline
\end{tabular}

عاشر اً: العلاقة بين درجة معرفة المبحوثين من العاملين بمر اقبة الاططلاق بأنثطتها في المجال

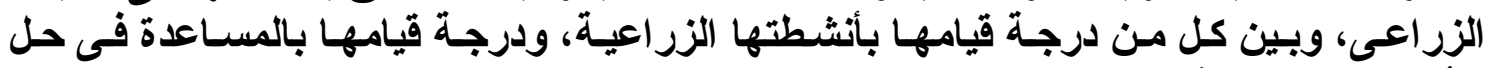

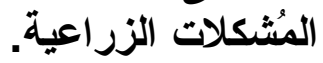

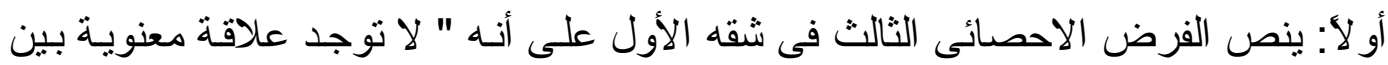

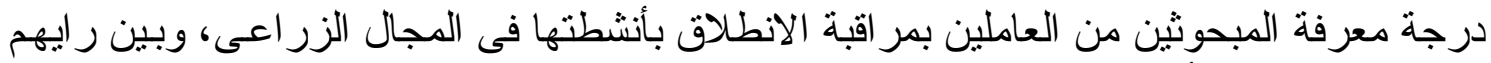

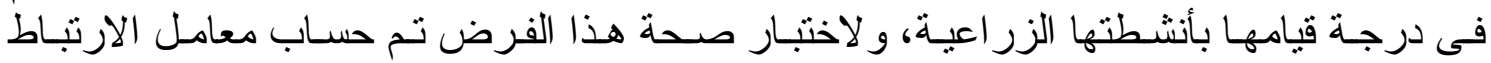

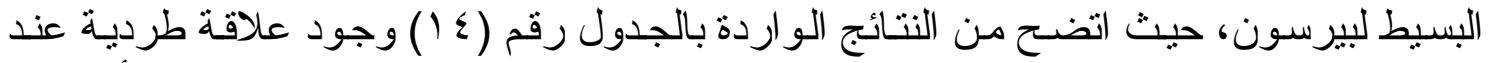

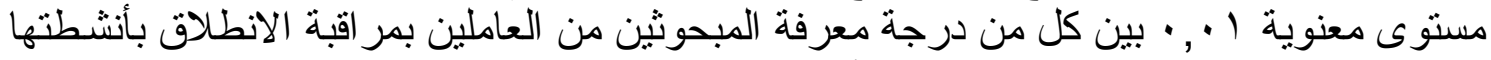

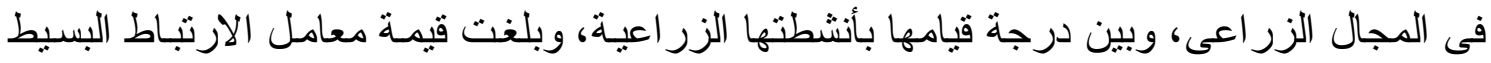

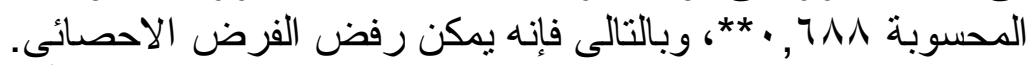

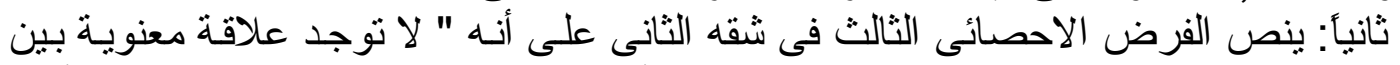

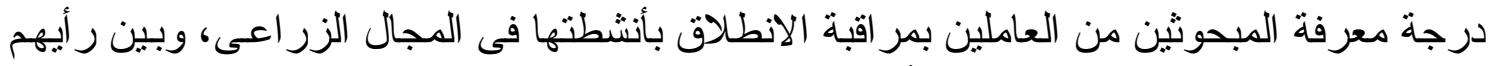

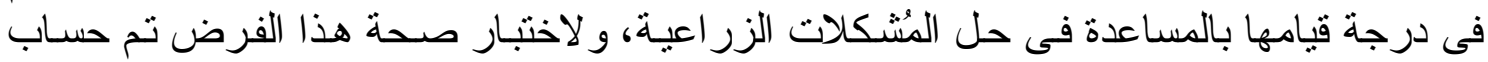

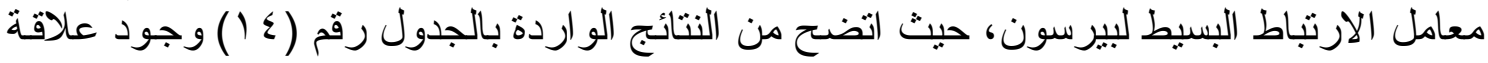

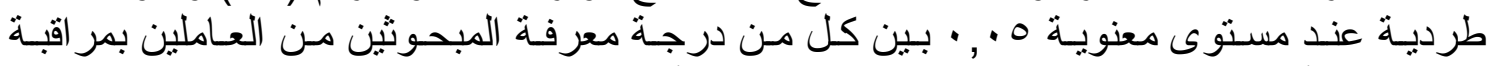

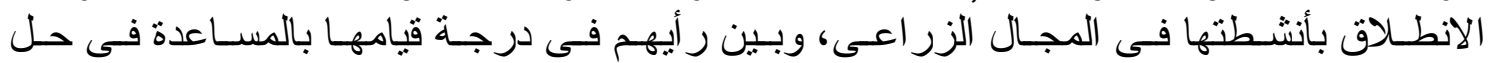

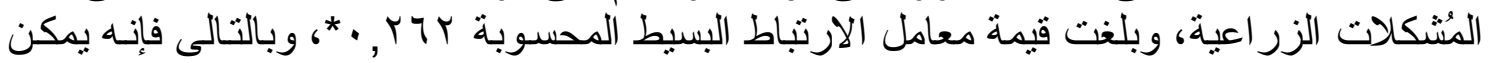

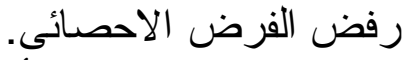

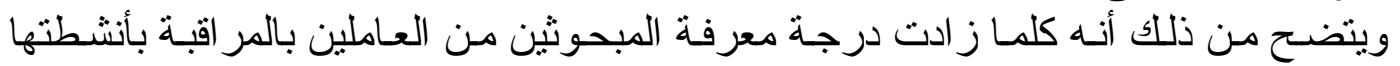

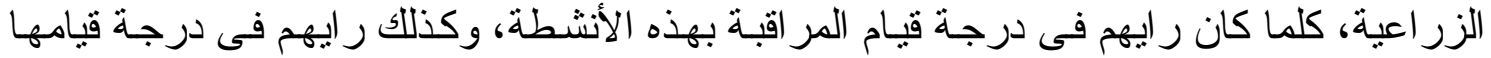

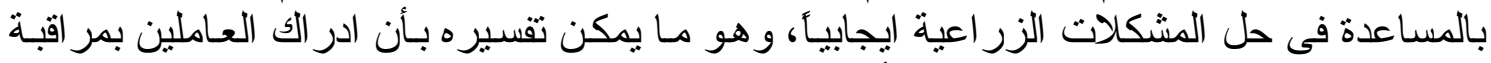

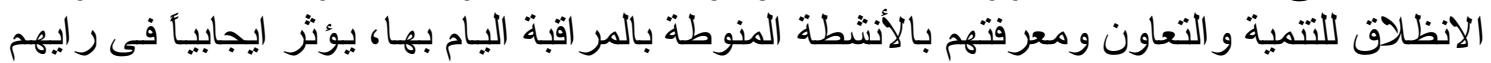

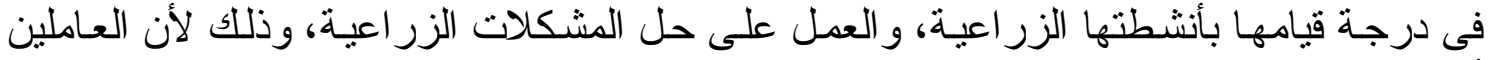
أنفسهم هم القائمين على ذللك. 


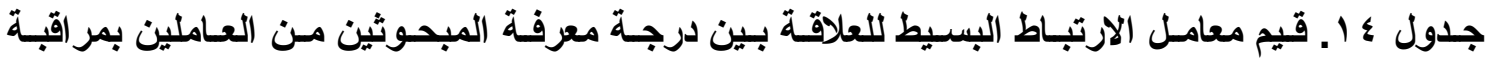

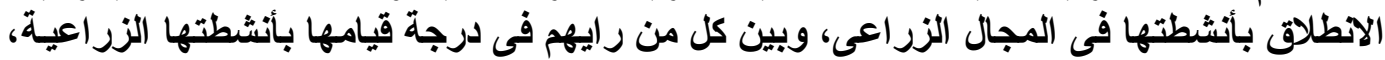

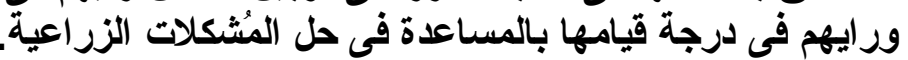

\begin{tabular}{|c|c|}
\hline 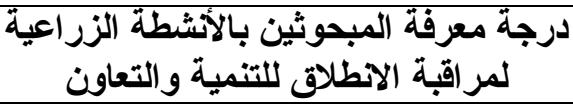 & \\
\hline$* *, \neg \wedge \wedge$ & رأى البمحوثين فى درجة قيام المراقبة بالأشطة \\
\hline *, & 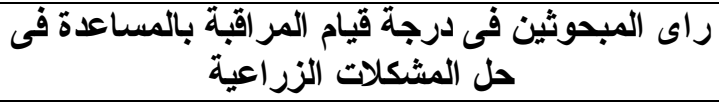 \\
\hline
\end{tabular}

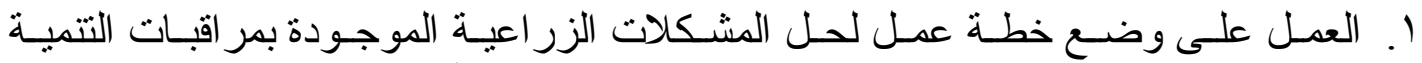

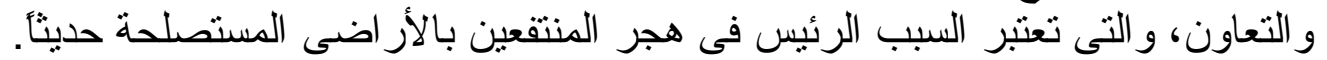

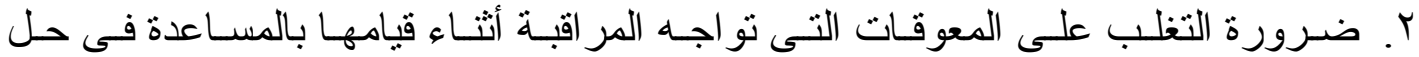

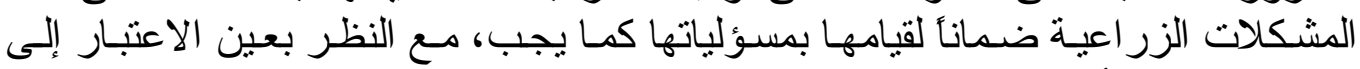

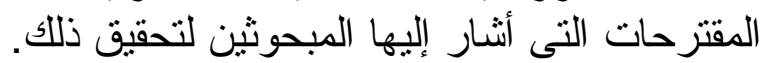

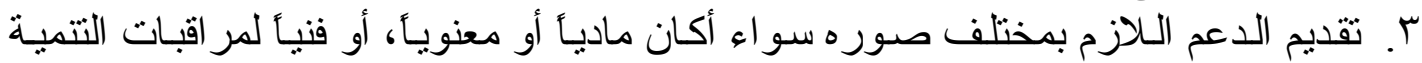

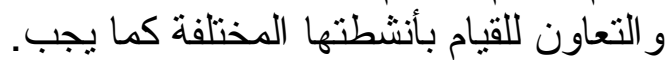
ع. التركيز على زيادة معرفة العاملين بمر اقبات التتمية و التعاون بالأنشطة التى يجب أنى أن تقوم

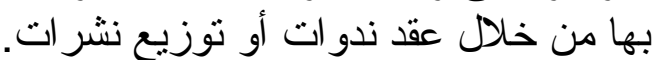

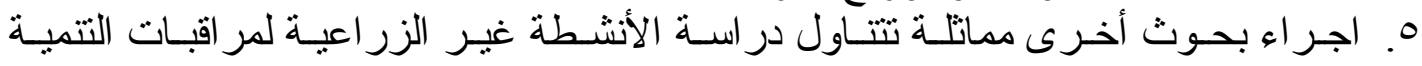
و التعاون.

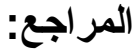
أبو النصر ، مدحت محمد، الثباب وصناعة المستقبل، الطبعة الأولى، المجموعة العربية للتدريب و النشر ،

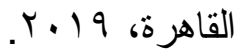

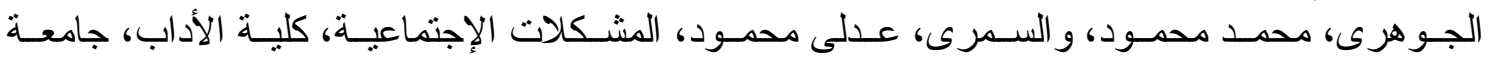

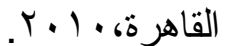

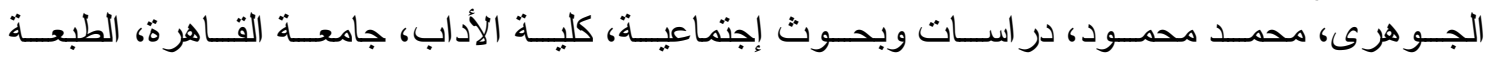

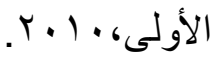
الخولى، الخولى سالم إير اهيم، المشكلات الإجتماعية المعاصرة فى المجتمع المصرى، دار الندى للطباعـة

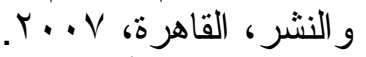

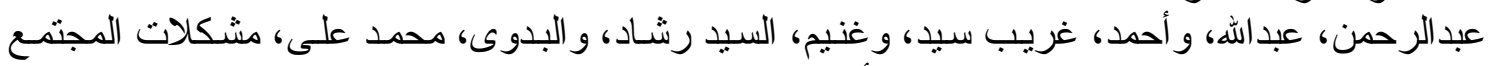

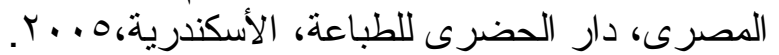

مديرية الزر اعة بالنوبارية، مر اقبة الانطلاق للتتمية و التعاون، نبذة مختصرة عن المر اقبة، 10 • ب. 


\title{
Agricultural Problems in Villages of Intelaq Directorate for Development and Cooperation in Beheira Governorate
}

\author{
Ismail Abdel-Malik Mohamed Ismail \\ Department of Economic and Agricultural Cooperative Sciences at the Higher Institute \\ for Agricultural Cooperation in Cairo
}

\begin{abstract}
This research aimed at determining the degree of the respondents' knowledge of workers in monitoring the launch of their activities in the agricultural field, as well as the degree of monitoring the launch for development and cooperation with their agricultural activities, and their opinion on the presence of agricultural problems in the study area, as well as their opinion on the degree of launch control for development and cooperation to help solve agricultural problems, and get to know On the obstacles facing monitoring by helping to solve agricultural problems from the viewpoint of the respondents, and their proposals to overcome these obstacles, and determining the significance of the relationship between the independent variables studied for the respondents and between: The degree to which the monitoring carried out its agricultural activities, and their opinion on the degree of the monitoring doing assistance to solve agricultural problems in the study area. And determine the significance of the relationship between the degree of the respondents' knowledge of the workers in monitoring the starting-up of the monitoring activities in the agricultural field, and each of: the degree of their carrying out these activities, and the degree of their assistance in solving agricultural problems.
\end{abstract}

The research sample consisted of 65 researchers from the start-up monitoring of development and cooperation, with $45 \%$ of the 143 monitoring workers representing the comprehensive research for the lake governorate. Pearson's simple correlation coefficient.

The most important results were as follows:-

It was found that approximately three fifths of the respondents $(57 \%)$ came in the high level of knowledge of the starting-up activities for development and cooperation, and more than half of the respondents $(55.4 \%)$ considered that the degree of monitoring of agricultural activities is high, and that nearly Two-thirds of respondents $(64.6 \%)$ believe that the level of agricultural problems in the observation area is high, and that nearly two-fifths of respondents $(38.5 \%)$ believe that the level of supervision in helping to solve problems is low.

It was also evident that there was a direct relationship between the variables of the number of training courses, the number of years of experience before joining the observation, and the opinion of the respondents on the degree of observation to help solve agricultural problems. Also, it was found that there is a direct relationship between the degree of the respondents' knowledge of workers in starting control of their activities in the agricultural field, and between each of: their opinion on the degree of observation of their agricultural activities, and the degree of their assistance in solving agricultural problems. The research ended with several recommendations that can be taken into consideration. 